\title{
Land-Sourced Pollution with an Emphasis on Domestic Sewage: Lessons from the Caribbean and Implications for Coastal Development on Indian Ocean and Pacific Coral Reefs
}

\author{
Andre DeGeorges ${ }^{1,2}, *$, Thomas J. Goreau ${ }^{1}$ and Brian Reilly ${ }^{2}$ \\ 1 Global Coral Reef Alliance, 37 Pleasant Street, Cambridge, MA 02139, USA; \\ E-Mail: goreau@ bestweb.net \\ 2 Department of Nature Conservation, Tshwane University of Technology, Private Bag X680, \\ 0001 Pretoria, South Africa; E-Mail: reillybk@tut.ac.za \\ * Author to whom correspondence should be addressed: E-Mail: andredeg@ verizon.net; \\ Tel.: +1-757-854-1303; Fax: +1-703-790-1578.
}

Received: 6 August 2010; in revised form: 5 September 2010 / Accepted: 9 September 2010 / Published: 14 September 2010

\begin{abstract}
This paper discusses land-sourced pollution with an emphasis on domestic sewage in the Caribbean in relation to similar issues in the Indian Ocean and Pacific. Starting on a large-scale in the 1980s, tropical Atlantic coastlines of Florida and Caribbean islands were over-developed to the point that traditional sewage treatment and disposal were inadequate to protect fragile coral reefs from eutrophication by land-sourced nutrient pollution. This pollution caused both ecological and public health problems. Coral reefs were smothered by macro-algae and died, becoming rapidly transformed into weedy algal lawns, which resulted in beach erosion, and loss of habitat that added to fisheries collapse previously caused by over-fishing. Barbados was one of the first countries to recognize this problem and to begin implementation of effective solutions. Eastern Africa, the Indian Ocean Islands, Pacific Islands, and South East Asia, are now starting to develop their coastlines for ecotourism, like the Caribbean was in the 1970s. Tourism is an important and increasing component of the economies of most tropical coastal areas. There are important lessons to be learned from this Caribbean experience for coastal zone planners, developers, engineers, coastal communities and decision makers in other parts of the world to assure that history does not repeat itself. Coral reef die-off from land-sourced pollution has been eclipsed as an issue since the ocean warming events of 1998, linked to global warming. Addressing ocean warming will take considerable international cooperation, but much of
\end{abstract}


the land-sourced pollution issue, especially sewage, can be dealt with on a watershed by watershed basis by Indian Ocean and Pacific countries. Failure to solve this critical issue can adversely impact both coral reef and public health with dire economic consequences, and will prevent coral reef recovery from extreme high temperature events. Sewage treatment, disposal options, and nutrient standards are recommended that can serve as a reference point but must be fine-tuned to local ecology.

Keywords: coral reefs; sewage; nutrients; land-sourced pollution

\section{Introduction}

"For no ecosystem is the impending catastrophe (of global warming) more imminent than for coral reefs, the source of most of the biodiversity, fisheries, sand, tourism, and coastal protection for over a hundred countries. No other habitat on earth is more sensitive to infinitesimal increases in global temperature, nutrients from sewage and fertilizers, agricultural and industrial chemicals, soil eroded from land following deforestation and unsustainable land use, and from raging epidemics of new emerging diseases" [1].

This paper is aimed at sensitizing marine biologists, developers, architects, engineers and decision makers in East Africa, the Indian Ocean, South East Asia, and the Pacific to the fragility of coral reefs, and the issues they must address if tourism development is to be ecologically sustainable and more acceptable to increasingly environmentally-sensitive clients.

The Caribbean and Atlantic contains $7.6 \%$ of the world's coral reefs, and were the first area to be extensively developed for tourism due to proximity to North America and Europe. The Indo/Pacific region (Pacific, SE Asia, and the Indian Ocean, including East Africa) have 92.4\% of global reefs, but are several decades behind the Caribbean in terms of tourism development. Africa, the last region to undergo large scale tourism development, hosts $21,323 \mathrm{~km}^{2}\left(8,232 \mathrm{mi}^{2}\right)$ of coral reefs, $7.5 \%$ of the world's total of 284,300 $\mathrm{km}^{2}\left(109,769 \mathrm{mi}^{2}\right)$ [2]. Most are found from the Egyptian Red Sea to Sodwana Bay, South Africa, and around the Western Indian Ocean islands. On the West African coast, little or no coral reef is found due to nutrient rich cold-water upwellings caused by currents linked to strong offshore winds such as the Harmattans. There one finds isolated rocky outcrops along the coast, rich in fish life, covered by thriving "soft" corals [3,4]. The major exceptions are small areas of reef in protected locations on offshore islands of Cabo Verde [5] and Sao Tome e Principe [6].

The Eastern African coastline is still relatively undeveloped, but is rapidly attracting tourism, with projects planned in Mombasa/Malindi and Lamu in Kenya, Zanzibar, Dar es Salaam to Tanga, Pemba and Mafia Islands in Tanzania, Pemba, Vilanculos and Greater Maputoland in Mozambique [7], as well as on the island states of the Seychelles, Mauritius, the Comoros, and Madagascar. Many investors from temperate climates have little or no understanding of coral reef ecology. Expansion in Southern Africa's coastal areas (e.g., Mozambique and to a lesser degree Tanzania/Zanzibar) is driven primarily by South African developers migrating up the coast. South Africa's coastal waters are too cold for corals, with the exception of the small and mostly protected area of northern KwaZulu-Natal including Sodwana and the Greater St. Lucia Wetlands. 
Little attention is being paid to lessons learned from the Caribbean (Figure 1), especially with regard to appropriate sewage treatment (brown and grey water), whose nutrient pollution is a major cause of reef degradation.

Figure 1. Structurally sound coral reef at $30 \mathrm{~m}$ depth, Roatan, Honduras, 1977. These reefs were coral dominated while algae were a minor component of this ecosystem. Source: DeGeorges, 1977.

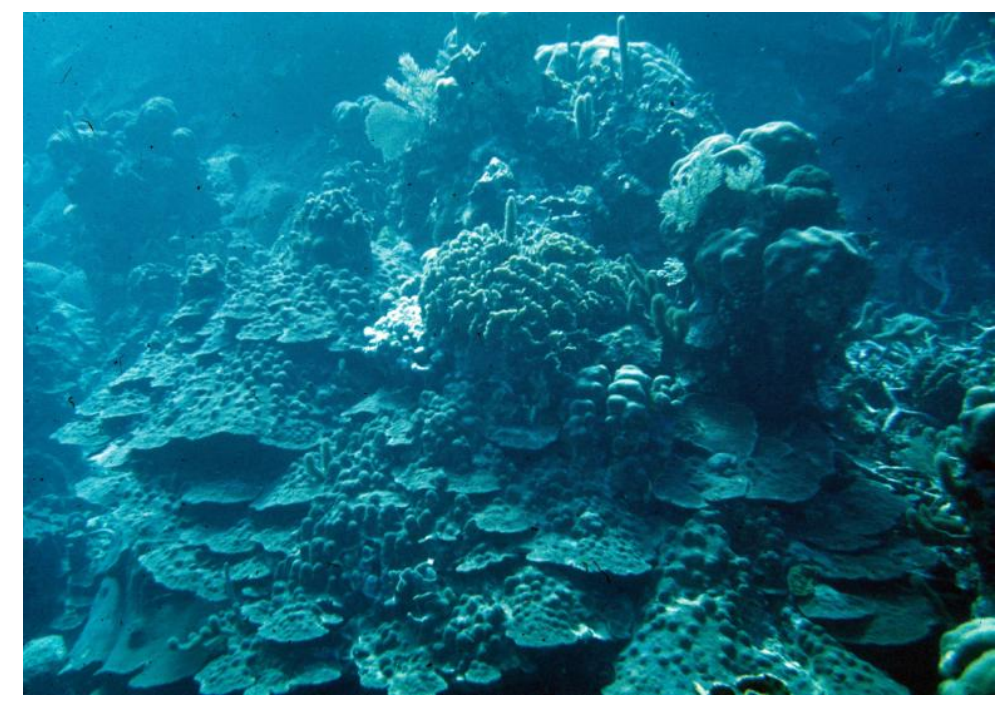

\section{The Relationship between Coral Reefs and Zooxanthellae}

Growth of reef-building (hermatypic) corals depends on the symbiotic relationship between coral polyps and unicellular algae called zooxanthellae [8]. Zooxanthellae are dinoflagellates living inside coral tissue. Symbiosis makes them different from planktonic dinoflagellates (including red tide algae which cause massive fish kills) and uniquely important to aquatic food chains. Zooxanthellae give most corals their colour and are also found in many other invertebrates including soft corals, giant clams (Tridacna spp.) and nudibranchs [9].

Zooxanthella photosynthesis causes reef formation by increasing growth of the coral's limestone skeleton. Light enhanced calcification enables healthy corals to grow faster than they are eroded by wave action and organisms such as boring sponges [8]. This is why light and thus depth are limiting factors to tropical reef-building corals. Zooxanthellae provide oxygen and recycle phosphates and nitrates from the coral's waste products, enabling an entire ecosystem to develop in unproductive, nutrient poor water. Efficient and rapid recycling of these nutrients results in the tropical world's coral reefs being one of the most productive natural and diverse communities, marine or terrestrial [8].

Corals without zooxanthellae, called ahermatypic corals, are not limited by light, grow at great depths and are mostly small, solitary, and slow growing, but they can form large colonies in deep or cold waters, for example in the soft corals shown from Cap Verte Peninsula, Dakar, Senegal, in West Africa (Figure 2). 
Figure 2. Typical ahermatypic soft corals, Cap Verte Peninsula, Senegal, 1984 impact of elevated nutrient concentrations on tropical coral reefs. Source: DeGeorges, 1984.

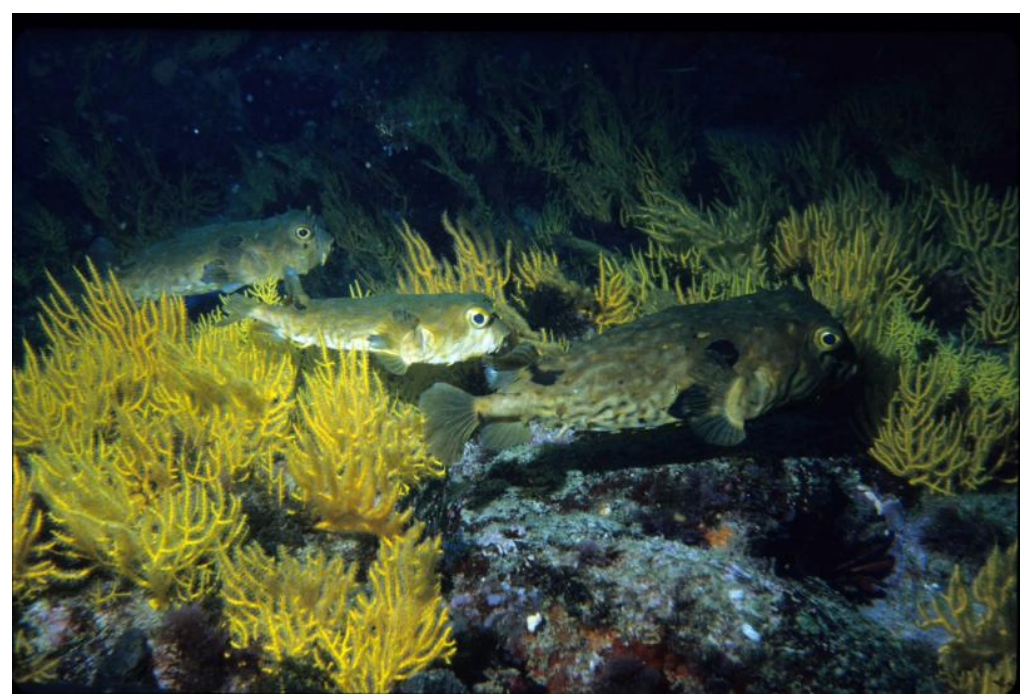

\section{3. "Top-Down" Versus "Bottom-Up" Control of Macro-Algae in Coral Reef Communities}

Excessive nutrient concentrations from pollution cause deleterious effects that can lead to demise of the coral reef community $[10,11]$. These include phytoplankton blooms, decreasing light penetration and photosynthesis of zooxanthellae, reducing coral productivity [11-18]. Reduced light penetration from algal blooms and coastal sedimentation also reduces photosynthesis of seagrass beds, causing their demise $[16,18]$. But the greatest impact of high nutrients comes from benthic macro-algae blooms that directly smother and kill corals [19]. All reefs near human populations suffer degradation from nutrient pollution. The "proliferation of benthic algae caused by enhanced nutrient inputs has led to competition with the hard corals, which the corals have lost. Thus, there can be a change in community structure from a hard coral dominated to an algal-dominated system" [20]. These changes can happen very quickly: in 1991 high nutrient indicating algae in Moorea, French Polynesia were confined to the immediate vicinity of sewage outfalls of the largest hotels, but by 1994 weedy algae were smothering corals throughout the northern lagoon [21].

Nutrient availability is the major factor limiting plant and algae growth rates, along with light (and water on land but not in the sea). This is especially true in shallow tropical waters with high light levels. All aquatic ecosystems turn eutrophic when harmful algae blooms (HABs) proliferate due to nutrient increase, and such HABs are increasing in frequency and intensity worldwide [22-24]. Coral reefs are the most nutrient-sensitive marine ecosystem, turning eutrophic at concentrations of nutrients so low that they would not affect mangroves, seagrasses, wetlands, lakes, or temperate marine ecosystems, [25-28]. Any aquatic ecosystem will go eutrophic if there are enough nutrients, but the nutrient concentrations causing coral reef eutrophication are so low that they would be considered oligotrophic in any other ecosystem. The next most sensitive marine ecosystem, seagrasses, require nutrient levels 20 to 30 times higher than coral reefs before weedy algae overgrow seagrasses [28].

Nevertheless, many coral reef ecologists believe overfishing of herbivores is of greater importance than nutrients in driving algae overgrowth of reefs. Most publications supporting this "top-down" hypothesis lack nutrient water quality data [29-32]. "Top downers" suggest the solution is to stop 
fishing. If this were the limiting factor in reefs, herbivorous fish populations would crash as fisheries intensified, causing reef algae to proliferate, so preventing fishing should cause corals and fish to recover. But in fact these patterns were not seen in the Caribbean: overfishing long preceded coastal tourism over-development, while sewage effluents and algae proliferation increased simultaneously whenever new areas were developed, and fish populations changed from being carnivore dominated (the preferred choice of fishermen) to becoming almost entirely herbivore dominated as algae became the only abundant food source [33]. Tanzania's rapid coral reef recovery from the 1998 ocean warming event compared to the poor recovery in Kenya has been attributed to closure of these areas to commercial fishing [34,35]. But analysis of Sea Surface Temperature data shows that temperatures in Tanzania in 1998 were not as high as that experienced in Kenya, and so coral mortality was much less [36].

The "bottom up" hypothesis proposed by Littler et al. [19], Bell [26], Lapointe et al. [27], Anderson et al. [37], Goreau [38] and Bell et al. [39] views nutrients as the primary control of marine plant production, but that herbivores, by eating some plants preferentially and avoiding others (often because they are toxic or too tough), influence which macro-algae are most abundant. McClanahan [40] notes that high abundance of unpalatable fleshy algae on reefs is often caused by eutrophication and reduces abundance of fish and their productivity, since herbivorous fish prefer earlier successional algal turfs. Therefore nutrients control the productivity of the algae community, but herbivores determine which species of algae are dominant. "Bottom uppers" argue that excessive macro-algae are best controlled by reducing nutrients rather than fishermen. This is opposed to the "top-down hypothesis", which blames artisanal fishermen for over-fishing herbivores and the die-off of algae-consuming sea urchins, but is often based on little or no water quality data [30]. McManus et al. [41] found that a reduction in herbivory from overfishing may enhance the likelihood of organic pollution causing a coral-algal phase shift, but a reduction in herbivory in the absence of eutrophication can also lead to the proliferation of algae. Efforts are underway in many parts of the world to integrate fisher communities into coastal zone management to mitigate adverse impacts from unmanaged fishing, such as community managed no-take fishery reserves. Tanzania is one of the leaders in this effort [42].

Littler et al. [19] found that "reduced nutrients alone do not prohibit fleshy algal growth when herbivory is low, and that high herbivory alone does not prevent fleshy algal growth when nutrients are elevated. However, reduced nutrients in combination with high herbivory virtually eliminate all forms of harmful micro- and macro-algae. It is our opinion that on the few remaining undisturbed, oligotrophic, coral reef systems, the effects of top-down inhibitory controls via intense herbivory prevail; whereas, bottom-up stimulatory controls are less prevalent, due to the lack of nutrient availability and over-compensatory consumption by grazers. However, eutrophic systems may lose their resiliency to inundation by macroalgae, with herbivores becoming swamped by bottom-up (nutrient induced) harmful algal blooms. Thus, the growth of reef-building corals can be inhibited under elevated nutrients relative to low nutrients, even though herbivory remains high".

In summarizing the two points of view, the "top downers" predict that "nutrients are irrelevant, and algae will disappear only if fishermen are prevented from fishing and/or if sea urchins reach dense populations"; "Bottom uppers" believe that only nutrient reductions will control macro-algae, whether there is fishing or not [38]. Appropriate and effective policy can only be formulated on correct 
assessment of the key causes of coral die-off. The authors' field experience worldwide support the "bottom-up hypothesis". Until massive coral bleaching and die-off due to recent ocean warming events starting in the 1980s, a major cause of coral die-off globally had been and continues to be nutrient pollution.

"The distinctions between the two theories are not academic if they affect practical management issues. Following the wrong paradigm will result in failed efforts at control. Because bottom-up and top-down theories recommend such different policy prescriptions (e.g., stopping fishing versus stopping sewage), effective management of algae on reefs will fail if the factor being controlled is not really the most important one" [38].

"The same pattern is seen in coral reefs all around the Caribbean, Indian Ocean, and Pacific: dense populations of algae-eating fish and sea urchins are found only at sites that have a lot of algae. While diseases and over-fishing can result in removal of herbivores, dense algae populations are found at all sites with nutrient sources, and are very low where these sources are absent, whether or not herbivores are present" [38].

Diadema antillarum sea urchins flourished on nutrient-polluted, macro-algal-covered dead reefs of Grand Anse Beach, Grenada in the late 1980s [43]. The only area where algae were absent, though exposing dead reef, was where Diadema were densely concentrated (Figure 3). Paddack et al. [44] found that "herbivorous fishes alone are incapable of excluding or removing macroalgae from reefs which have lost a majority of their coral cover. Intense grazing by Diadema antillarum may be crucial for removal of established macroalgae and thus long-term recovery of Caribbean reefs".

Figure 3. Dense concentrations of macro-algal grazing Diadema antillarum sea urchins flourish off Grand Anse Beach, Grenada, 1988 clearing patches of algae where nutrient pollution was known to have caused the algae to smother and kill the coral. Note the masses of dead coral rubble, the result of catastrophic coral mortality from disease in the late 1970s. Source: DeGeorges, 1988.

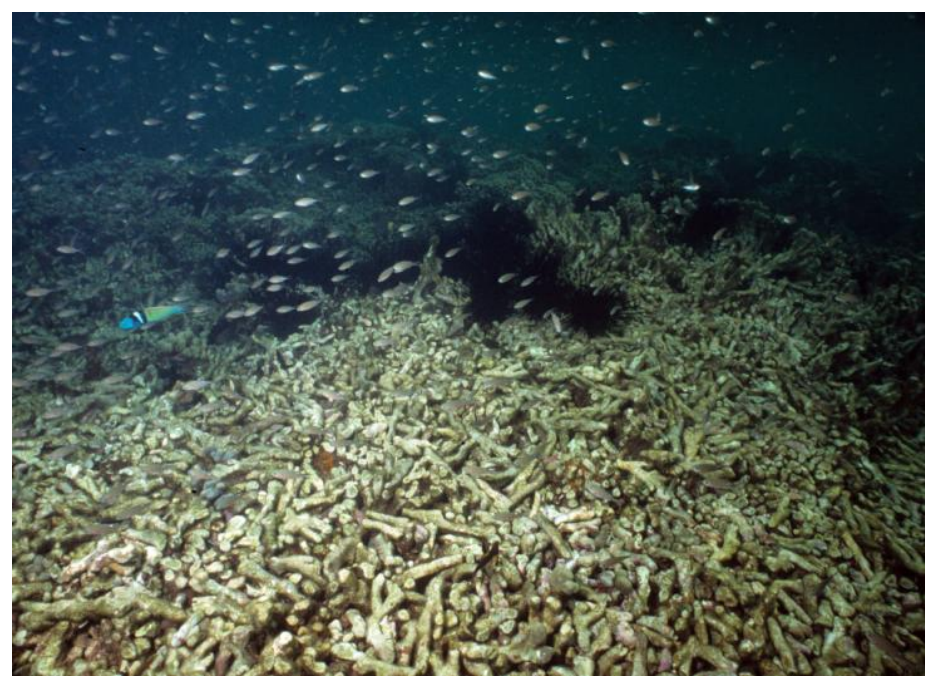

A positive relationship between herbivorous fish biomass and macroalgae was found in the Netherland Antilles, but coral cover was not correlated with the biomass of any fish groups [45]. This 
pattern of very high herbivore grazing focused where nutrients are highest is also seen in many places around the Caribbean, and in the Western Indian Ocean, for example in the Maldives [17].

\section{Sources of Nutrient Pollution, the Caribbean Experience}

Nutrient pollution results from sewage ("brown water"), wash water (“grey water") and agricultural runoff (fertilizer and natural components of soils) [11,46]. Other sources include bird's nests, turtle and dolphin enclosures/farms, fish farms, garbage dumps, fish cannery abattoir wastes, bird rookeries, and seasonal upwelling. Transport of pollutants from distant watersheds by rivers is a problem in Belize, Trinidad and Tobago, and Madagascar. Upwelling of nutrients from deep cold waters is an important factor controlling algae abundances in areas not affected by land sources, for example in the Turks and Caicos Islands [47] and Eastern Caribbean, and is likely to be an even greater factor in Indo-Pacific areas with shallow thermoclines (for example in the Arabian Sea or the Gulf of Panama) since nutrient levels in deep Indian Ocean and Pacific waters are around twice as high as in the Atlantic. Watershed degradation, from physical alteration and destruction of habitats (PADH) in East and Southern Africa has been identified as acute for the Tana, Athi-Sabaki, Rufiji and Zambezi rivers, as well as in the Pangani, Limpopo and Betsiboka watersheds [46]. Sedimentation and other pollutants (e.g., nutrients \& pesticides) from degraded watersheds adversely impact floodplains, estuaries, mangroves, sea grass and seaweed beds, coral reefs and coastal fisheries dependent on these ecosystems [48]. Regardless of the causes, "coral reefs affected by overfishing, destructive fishing, land runoff, nutrient and other pollution will be more vulnerable to increases in water temperature and ocean acidification" [49].

There are only a few cases where the effects of long-term reversal of reef eutrophication have been monitored. Diversion of a large sewage discharge from Kaneohe Bay, Hawaii, resulted in a dramatic recovery of the nearby coral reef. [50], but this was later reversed when suburbanization of the watershed caused non-point discharges of golf course and lawn fertilizers and road runoff that did not go into the sewer system. In Dragon Bay, Jamaica, where all nutrient inputs were stopped in 1996 by recycling sewage effluents for irrigation on land, weedy algae smothering a reef began to die back in weeks and were gone in two months [38]. Thirteen years later this reef was still free of high nutrient-indicating algal species and the corals are recovering.

\section{Impacts of Macro-Algae on Coral Reef \& Coastal Ecology and Coral Physiology, the Caribbean Experience}

The most observable effect of nutrient pollution is smothering of coral by benthic macro-algae that cut off light needed by zooxanthellae to photosynthesize, block coral polyps from filtering food out of surface waters, and prevent settlement of coral larvae [11-13,38,51-61]. Without access to light and zooplankton food, the coral dies (Figure 4).

Goreau [38] noted that the best way to stop algae from taking over coral reefs is to cut off sources of nutrient enrichment, which "push the system to algae that cannot be eaten (grazed upon) because they are too toxic, too tough, or very dense rapidly growing turf algae that are too short or fast growing to be grazed" [25,38]. A clear example of this can be seen in Barbados, the most densely populated island in the Caribbean, where chronic pollution, despite the presence of heavy grazing by parrotfish 
(which were not eaten locally until recently) and a recovery of high densities of the grazing black sea urchin Diadema antillarum, has resulted in dense turfs of algae over dead reefs. As eutrophication proceeded, the turfs were then replaced by cyanobacteria (blue-green algae), which grazers refuse to eat. In the last few years improved sewage treatment in Barbados has resulted in a reversal in which cyanobacteria have been replaced by algal turf.

Loss of coral sets off a cycle of beach erosion. Live coral (along with coralline algae), breaking down gradually over time, is lost as a source of sand replenishment, while protection from wave and storm action is lost as the reef structure collapses due to internal boring organisms. Declining artisanal fisheries from habitat loss, and increasing eye, ear and skin infections affecting tourists, has the net result of diminishing tourism quality.

Figure 4. Porites porites "finger coral" being smothered by macro-algae, Dictyota sp., from inappropriate septic tanks, Grand Anse Beach Grenada, 1988. Similar patterns are seen around densely populated coastal areas and tourism areas worldwide. Source: DeGeorges, 1988.

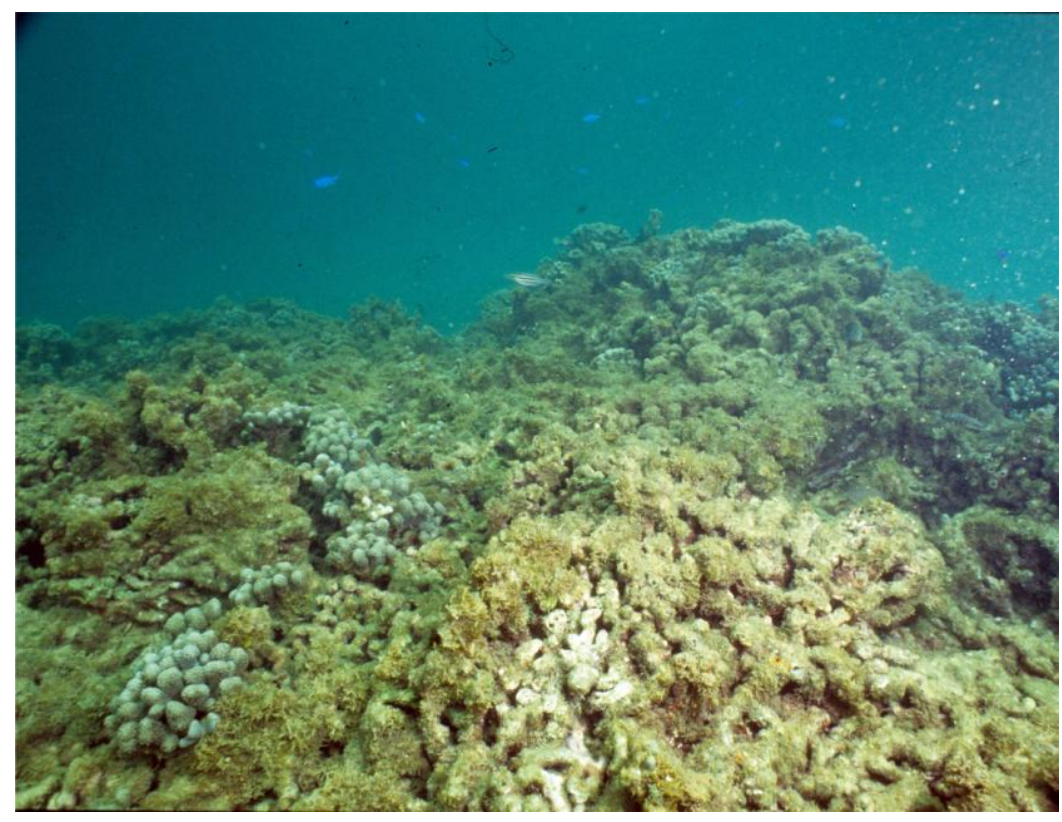

\section{Recommended Nutrient Water Quality Criteria, the Caribbean Experience}

The following nutrient concentrations are typical of "non-polluted marine waters" in the Eastern Caribbean [62] (Table 1).

Table 1. Background nutrient concentrations in unpolluted Eastern Caribbean waters. Adapted from [62].

\begin{tabular}{ccc}
\hline Parameter & ug-at/L \& $\mathbf{~ m g / L}$ & ug-at/L \& $\mathbf{~ m g / L ~}$ \\
\hline & $\begin{array}{c}\text { Coastal Waters } \\
\text { (Nearshore) }\end{array}$ & Oceanic Waters \\
Nitrate $\left(\mathrm{NO}_{3}+\mathrm{NO}_{2}\right)$ as $\mathrm{N}$ (Unfiltered) & $0.70 \& 0.01$ & $0.35 \& 0.005$ \\
Total Phosphate Phosphorus as P (Unfiltered) & $0.10 \& 0.003$ & $0.06 \& 0.002$ \\
\hline
\end{tabular}


Hunte who established the standards in Table 1, recommended the following ambient marine water quality standards for nutrients to protect coral reefs because of "concern that nitrite, nitrate and (ortho) phosphate may be poor indicators of nutrient loading of the coastal zone as they are rapidly removed from the water column by algal assimilation" [63]:

- Total nitrogen (Total Kjeldahl Nitrogen = organic nitrogen + ammonia): $10 \mu \mathrm{g} / \mathrm{L}$ or $0.01 \mathrm{mg} / \mathrm{L}$

- Total phosphate phosphorus (Total filterable + Non-filterable Phosphate [64]: $2.5 \mu \mathrm{g} / \mathrm{L}$ or $0.0025 \mathrm{mg} / \mathrm{L}$

Lapointe [65] provides even lower recommended nutrient water quality threshold standards to protect coral reefs, based on measured nutrient concentrations corresponding to the transition from coral to algae dominance in the Caribbean, which are identical to those found in the Great Barrier Reef by Bell [26]. These recommended water quality standards are shown in Table 2 [26,27,38,65-67].

Table 2. Recommended ambient nutrient water quality standards in nearshore waters, not to be exceeded: "threshold concentrations" to protect coral reefs from overgrowth of macro-algae. Data from [26,27,38,65-67].

\begin{tabular}{|c|c|}
\hline Parameter & $\begin{array}{l}\text { Not Exceeding mg/L (ppm) } \\
\text { (umole/L) }\end{array}$ \\
\hline $\begin{array}{l}\text { Dissolved Inorganic Nitrogen }(\mathrm{DIN})=\text { Dissolved (Filterable) } \\
{\left[\text { Nitrate }\left(\mathrm{NO}_{3}+\mathrm{NO}_{2}\right)+\text { Ammonia] as } \mathrm{N}\right.}\end{array}$ & $0.014 \mathrm{mg} / \mathrm{L}$ ( 1 umole/L as $\mathrm{N}$ ) \\
\hline $\begin{array}{l}\text { Soluble Reactive Phosphorus (SRP) = Dissolved (Filterable) } \\
\text { Orthophosphate as P }\end{array}$ & $0.003 \mathrm{mg} / \mathrm{L}(0.1 \mathrm{umole} / \mathrm{L}$ as $\mathrm{P})$ \\
\hline
\end{tabular}

Lapointe [68] noted that "Total $\mathrm{N}$ and Total $\mathrm{P}$ are not the preferred indices as they contain particulate forms of $\mathrm{N}$ and $\mathrm{P}$ that are unavailable to reef biota (i.e., unreactive). The efficacy of these DIN (Dissolved Inorganic Nitrogen) and SRP (Soluble Reactive Phosphorus) thresholds was proven in South Florida when water managers pumped massive amounts of farm runoff through the Everglades into Florida Bay and the Florida Keys National Marine Sanctuary (FKNMS) in the mid-1990s ... which led to the demise (38\% loss of coral throughout the FKNMS between 1996 and 1999 following the nutrient enrichment event) (only $\sim 6 \%$ coral cover left)". Similarly, Littler et al. [19] reference comparable low nutrient levels (i.e., $\sim 0.10$ umole/L SRP, $\sim 1.0$ umole/L DIN) correlated with macro-algal blooms and the subsequent decline of coral reefs from eutrophication at Kaneohe Bay in Hawaii, fringing reefs of Barbados, inshore reefs within the Great Barrier Reef lagoon and reefs of the Houtman Abrolhos Islands off Western Australia. These low nutrient concentrations were also experimentally corroborated with Lapointe et al. [27] for macro-algal overgrowth of seagrass and coral reef communities along natural nutrient gradients on the Belize Barrier Reef. Littler et al. [19] "recognize that coral reef organisms can tolerate higher levels of DIN and SRP; however, these nutritional levels represent tipping-point concentrations that reduce resiliency to a point at which coral-reef ecosystems can potentially shift towards dominance by fleshy algae." 
The recommended water quality parameters from the Caribbean and Indo-Pacific provide a basis for developing similar standards for coral reefs worldwide that should be based upon a combination of monitoring coral/algal cover and water quality. We note that water quality standards based on concentrations do not necessarily translate directly to acceptable nutrient discharge rates, because the concentration is also dependent on the rate of dilution by currents. The same nutrient discharge rate will result in lower concentrations in areas with higher tidal currents, so the acceptable loading depends on local factors, and must be evaluated site by site accordingly. Areas with low tides, like the Caribbean, will be more vulnerable to the same discharge rate than areas with large tides, such as Tanzania and Madagascar.

\section{Indicator Genera of Macro-Algae Associated with Land-Sourced Nutrient Pollution, the Caribbean Experience}

Goreau [38] noted that "algae distributions are in fact a better indicator of nutrient inputs than the nutrient concentrations themselves. The reason for this is that nutrients vary very quickly in space and time as the pattern of water movement shifts with currents, tides, winds, and waves, and because they can be rapidly taken up by algae. If seriously eutrophic waters remain over a reef for long enough, algae will remove most or all of the nutrients. As a result a eutrophic reef can have low measurable nutrients in the water, because they have been taken up and are part of the algae biomass, to be released again when the algae dies and decomposes".

Large increases in macro-algae, such as Lobophora sp. and Dictyota sp., prevent recruitment and settlement of coral larvae. Among the most common genera of benthic algae that turned Caribbean coral reefs into algal reefs in the early stages in the 1980s were the following species [11]:

- Turbinaria sp., a brown algae, family Cystoseiraceae

- Lobophora variegata, a brown algae, family Dictyotacae

- Dictyota spp., a brown algae, family Dictyotacae

- Halimeda spp., a green algae, family Halimedaceae

- Amphiroa sp., a red algae, family Corallinaceae

Some macro-algae are largely characteristic of low (Turbinaria sp., Amphiroa sp., Halimeda sp., Padina sp.) to moderate (Dictyota spp., Lobophora sp., Digenea simplex, Laurencia intricata, Acanthophora spicifera) nutrient pollution, but they are among the first to increase strongly as nutrient inputs increase. They are then replaced by other, worse, species, primarily fleshy green algae, red algae, and cyanobacteria, as nutrients become higher. Some of these high nutrient indicating algae identified by Lapointe, et al. [61] and Goreau [69]:

- Dictyosphaeria cavernosa, a green algae, family Valoniaceae

- Ulva fasciata \& lactuca, green algae, family Ulvaceae

- Enteromorpha sp., green algae, family Ulvaceae

- Chaetomorpha linum, green algae, family Chladophoraceae

- Cladophoropsis macromeres, green algae, family Chladophoraceae

In the Indian Ocean, the brown algae Turbinaria sp. [70] and Sargassum sp. [70,71] were nutrient pollution indicators off of Mahé and St. Anne Marine Park, the Seychelles. Off Sri Lanka, 
Rajasuriya [72] found that overgrowth by Halimeda spp., various filamentous algae and sedimentation appear to inhibit recruitment and growth of corals. These indicate that nutrient concentrations were lower than in the Caribbean at that time.

Along the Kenyan coastline, dominance of the eutrophic green algae (Ulva sp. and Enteromorpha sp.) were observed adjacent to heavy tourism infrastructure development, with macro-algal cover of up to 69\% [46]. These algae are typical of severely polluted waters. Cyanobacteria (blue-green algae) mats, Chaetomorpha sp., the fleshy red alga Centroceras clavulatum, Enteromorpha sp. over-growing corals were found to indicate high levels of nutrients in the Maldives, which has a mean population density of over 700 persons $/ \mathrm{km}^{2}$, reaching a peak of nearly 40,000 people $/ \mathrm{km}^{2}$ in Male [17]. Cyanobacteria were also noted to be an indicator of heavy nutrient pollution in Mauritius reefs [73]. Microdictyon sp. and Cladophoropsis sp. were found to be indicators of natural nutrient enrichment from upwelling in the Seychelles [74] and in the Turks and Caicos Islands [47]. During the severe 1998 bleaching event that killed most corals in Seychelles, massive benthic algae blooms covered dead coral, fuelled by nutrients from rotting of dying corals. In areas with high land-sourced nutrient inputs, benthic algae blooms permanently remained covering dead corals [71,74] but in areas with low nutrient backgrounds, encrusting pink calcareous red algae took over dead coral after the 1998 ocean warming event [75]. These were mostly Porolithon sp., but included at least three other genera indicative of clean low nutrient waters, since encrusting calcareous red algae are quickly overgrown by filamentous algae or by large fleshy algae if nutrients are only slightly elevated.

\section{Land-Sourced Pollution in the Indo-Pacific}

Land-sourced marine pollution in the Indo-Pacific is primarily associated with densely populated areas and industrial zones in urban centres and near river discharge points. These centres of pollution tend to be isolated, sometimes by hundreds of kilometres, creating algae dominated reefs near pollution hotspots (e.g., Sharm El Sheikh, Malindi to Mombasa, Tanga, Dar es Salaam, Old Town Zanzibar, Pemba, Beira, Maputo, Victoria, Port Louis, Boracay, Jakarta, Manila, Cebu, Makassar, etc.). However, rapid urbanization and development of coastal tourism such as the greater Bazaruto Archipelago, Mozambique if not adequately addressed, could result in "strip development" [46] as in the Caribbean that could, and in some places is already, causing widespread reef degradation (for example Boracay in the Philippines, Ko Samui and Phuket in Thailand, Kenting in Taiwan).

The consequences of coral die-off, be it from land-sourced pollution or ocean warming are similar; dead reefs, increased beach erosion, decreased fishery habitat, public health issues, declining tourism, and ultimate loss of key economic sectors. One might challenge the importance of land-sourced pollution when the consequences of ocean warming events on coral die-off were as much as 10 times that from other causes in the Seychelles and much of the Western Indian Ocean (e.g., sediment from land or dredging, algae overgrowth, tourist and anchor damage, storm waves, or coral-eating crown of thorns starfish) [71], resulting in 75-99\% loss of live coral [36,76]. However, corals have begun recovering from this ocean warming event $[49,74]$. Recovery can be enhanced by diminishing stresses like land-sourced pollution. Ocean warming must be dealt with through long-term international negotiations, but land-sourced pollution can be dealt with immediately at regional and local levels. 
In the Indo-Pacific, as in most countries, most sewage is not treated at all, and even when it is treated in urban areas or tourist areas, it is almost never treated past the secondary stage. Secondary treatment gets rid of human pathogens and to some degree, makes waters "safe" for humans to swim in, but it leaves almost all the nutrients dissolved in the effluent water. It is precisely those nutrients, which do not affect human health, that are deadly to coral reefs. Only one country in the world, the Turks and Caicos Islands in the Caribbean, makes it a policy that all developments must treat their sewage to secondary level, and then recycle all the waste water as irrigation on their own property [47]. This model needs to be applied wherever coral reefs are affected by land-sourced pollution.

\section{Estimates of Municipal \& Industrial Pollution, Western Indian Ocean}

Estimates of municipal and industrial pollution off East Africa/Western Indian Ocean date back to the early 1980s [77]. Pollutants from municipal wastewaters entering coastal waters of the Western Indian Ocean are estimated in Table 3. South Africa appears to be one of the few countries with modern sewage treatment plants; however, effluent from primary or secondary treatment plants does not adequately remove nutrients that threaten coral reefs and grass beds as discussed below.

Grey water from the 700,000 annual tourists plus 1.2 million permanent residents in Mauritius, one of the most densely populated countries in the region [78], is having a major impact on nearshore water quality [73]. In the Maldives high levels of nutrient-indicating algae are found on reefs around the major population centre, Male, and localized where resort waste waters enter the ocean [17].

In the Tanga coastal area of Tanzania, excessive nutrient loading from municipal and industrial effluents, including a fertilizer factory, is stimulating proliferation of macro-algae in coastal waters [46,48]. Off Zanzibar nutrient pollution is resulting in algal blooms and decreased cover of coral-reef-building algae [46]. As a major contributor to coastal pollution off Tanga, effluents from 20 sisal factories discharge into the Pangani River. Domestic sewage is a major source of marine pollution in the city of Dar es Salaam [48].

Table 3. Representative estimated loads pollutants \& volumes of municipal wastewater into coastal areas of the Western Indian Ocean. Adapted from [46].

\begin{tabular}{|c|c|c|c|c|c|}
\hline \multirow[b]{2}{*}{ Country } & \multicolumn{4}{|c|}{ Estimated Loads (tonnes/year) } & \multirow[b]{2}{*}{$\begin{array}{c}\text { Estimated volume of municipal } \\
\text { wastewater }\left(\mathrm{m}^{3} / \text { day }\right)\end{array}$} \\
\hline & BOD (1) & $\begin{array}{c}\text { Suspended } \\
\text { Solids } \\
\end{array}$ & $\begin{array}{c}\text { Nitrogen } \\
(2)\end{array}$ & $\begin{array}{l}\text { Phosphorous } \\
\text { (2) }\end{array}$ & \\
\hline Comoros & 489 & 1,063 & 212 & 26 & 168 \\
\hline Kenya & 2,744 & 3,889 & 802 & 97 & 145,500 \\
\hline Madagascar & 2,962 & 6,869 & 1,417 & 172 & \\
\hline Mauritius & 598 & 1,388 & 286 & 35 & $130,420(173,500$ after extension of system $)$ \\
\hline Mozambique & 1,137 & 1,203 & 108 & 26 & 29,149 \\
\hline Seychelles & 541 & 1,254 & 259 & 31 & $4,922(10,372$ after extension of system) \\
\hline South Africa & 39,502 & 30,478 & 4,518 & 2,259 & $\begin{array}{l}255,000 \text { (offshore, } 1^{\circ} \text { treatment) } \\
46,300 \text { (surf zone, } 2^{\circ} \text { treatment) } \\
31,500 \text { (estuaries, } 2^{\circ} \text { treatment) }\end{array}$ \\
\hline Tanzania & 21,741 & 50,413 & 10,398 & 1,260 & 37,912 \\
\hline $\begin{array}{l}\text { (1) Biolc } \\
\text { (2) Not ir }\end{array}$ & $\begin{array}{l}\text { l Oxygen } \\
\text { ted in wl }\end{array}$ & $\begin{array}{l}\text { emand is a } \mathrm{r} \\
\mathrm{h} \text { form estim }\end{array}$ & $\begin{array}{l}\text { easure of o } \\
\text { te is made }\end{array}$ & $\begin{array}{l}\text { gen depleting } \mathrm{C} \\
\text { g., as } \mathrm{P} \text { or } \mathrm{P}_{4} \text {, }\end{array}$ & $\begin{array}{l}\text { ganic material } \\
\left.\mathrm{N} \text { or } \mathrm{NO}_{3}\right)\end{array}$ \\
\hline
\end{tabular}


Industrial effluents appear to be primarily oxygen-consuming organic materials (BOD) from agro-industries in Western Indian Ocean countries (Table 4).

Table 4. Industrial Pollutants, Western Indian Ocean.

\begin{tabular}{|c|c|c|c|c|c|c|c|c|}
\hline \multirow[t]{2}{*}{ Country } & \multirow[t]{2}{*}{$\begin{array}{l}\text { Source of } \\
\text { Pollution } \\
\end{array}$} & \multicolumn{6}{|c|}{ POLLUTANTS } & \multirow[t]{2}{*}{$\begin{array}{l}\text { Data } \\
\text { from }\end{array}$} \\
\hline & & BOD & \begin{tabular}{|c} 
Suspended \\
Solids
\end{tabular} & $\begin{array}{l}\text { Solid } \\
\text { Waste }\end{array}$ & Nitrogen & Total P & Heavy Metals & \\
\hline Comoros & Agro-industries & $\begin{array}{l}\text { Significant, } \\
\text { small } \\
\text { compared to } \\
\text { domestic } \\
\text { waste }\end{array}$ & $\begin{array}{l}\text { Same as } \\
\text { BOD }\end{array}$ & - & - & - & - & [46] \\
\hline Kenya & 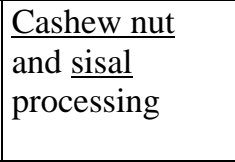 & $\begin{array}{l}\text { High from } \\
\text { sisal waste }\end{array}$ & $\begin{array}{l}\text { High from } \\
\text { sisal waste }\end{array}$ & $\begin{array}{c}15,330 \& \\
8,400 \\
\text { tonnes/yr } \\
\text { respectively }\end{array}$ & - & - & - & [46] \\
\hline \multirow[t]{2}{*}{ Mauritius } & 31 industries & $\begin{array}{c}1,117 \\
\text { tonnes/yr }\end{array}$ & $\begin{array}{c}2,306 \\
\text { tonnes/yr }\end{array}$ & - & 17 tonnes/yr & $\begin{array}{c}81 \\
\text { tonnes/yr }\end{array}$ & - & [46] \\
\hline & $\begin{array}{l}\text { Agricultural } \\
\text { Runoff }\end{array}$ & - & - & - & $\begin{array}{l}\text { Coral reefs } \\
\text { degraded by } \\
\text { sediment } \& \\
\text { nutrients }\end{array}$ & - & - & [79] \\
\hline Mozambique & $\begin{array}{l}137 \text { Industries } \\
\text { around } \\
\text { Maputo, } \\
\text { Matola \& } \\
\text { Beira: textile, } \\
\text { paper, tyre, } \\
\text { brewery; } \\
\text { discharging } \\
\text { untreated } \\
\text { wastewater }\end{array}$ & $\begin{array}{c}79,388 / \text { yr in } \\
1996\end{array}$ & - & - & - & - & $\begin{array}{l}\text { Unquantified } \\
\text { heavy metals }\end{array}$ & [46] \\
\hline Seychelles & Agro-industries & $17.7 \%$ of total & $\begin{array}{c}6.7 \% \text { of } \\
\text { total }\end{array}$ & - & - & - & & [46] \\
\hline $\begin{array}{l}\text { Zanzibar, } \\
\text { Tanzania }\end{array}$ & \begin{tabular}{|l} 
Food \\
processing \\
(slaughter \\
houses, dairy, \\
beverages) \& \\
soap)
\end{tabular} & 15 tonnes/yr & $\begin{array}{c}16 \\
\text { tonnes/yr }\end{array}$ & - & - & - & - & [46] \\
\hline & $\begin{array}{l}\text { Various } \\
\text { industries in } \\
\text { Stone Town. }\end{array}$ & - & - & - & - & - & $\begin{array}{l}\text { Significant } \\
\text { levels of } \\
\text { aluminium \& } \\
\text { cadmium in } \\
\text { macroalgae } \\
\text { from } \\
\text { Chapwani \& } \\
\text { Changuu } \\
\text { Islands off } \\
\text { Zanzibar }\end{array}$ & {$[46]$} \\
\hline
\end{tabular}




\section{Land-Sourced Pollution and Coral Reef Degradation, the Seychelles}

Prior to the 1998 ocean warming event, many of the 114 outer islands in the Seychelles contained extremely healthy coral reef habitat; $60-90 \%$ healthy coral cover pre-ocean warming compared to less than 5\% at most locations after 1998 [36].

Signs of land-sourced pollution in the Seychelles were identified as areas where corals in moderate nutrient areas were covered with a fine greenish brown algal turf, and in high nutrient areas were covered with large fleshy algae (mostly Sargassum) or with slimy mats of cyanobacteria (blue-green algae) [71]. High levels of algae are found along the west side of Ste. Anne Island facing the capital city Victoria, Seychelles major source of nutrient pollution [75].

In 1990, underwater survey observations by the principal author identified heavy cover of Sargassum spp. algae smothering the nearshore fringing corals of Mahé, the Seychelles (Table 5, Figure 5), and macro-algae filling spaces between the branches of Acropora/Porites corals at St Anne Marine National Park, an island a couple of kilometres off Mahé, the Seychelles. This could be indicative of nutrient pollution from inadequately treated and disposed waste between Victoria and the airport on Mahé, where most of the population lives. The permanent resident population of Victoria alone (23,000 people), is estimated equivalent to fertilizing the nearshore coastal waters with $17,300-17,700 \mathrm{~kg}$ (38-39,000 fifty pound bags) of 20/10/10 (NPK)/year fertilizer from human waste disposal. If all these nutrients are available for algae production, depending on the limiting nutrient, between 3.6 and 6.4 million $\mathrm{kg}$ (8-14 million pounds) dry weight of algae could be produced per year in Victoria's nearshore coastal waters. Examined in this light, it is no wonder that macro-algae could out-compete and over-grow corals that have evolved to rapidly recycle nutrients in nutrient poor tropical waters. Goreau [71] observed that "the algae overgrowth that is spreading outward from population centres such as Victoria as population rises and more sewage discharge results in higher nutrient inputs to the coastal zone, thereby fertilizing rapid algae proliferation".

Ahamada, et al. [79] identify deforestation and poor agricultural practices causing major soil erosion around Victoria and St. Anne Marine Park (20,000 visitors/year). There is no quantitative data to determine which has been more devastating, siltation of sediment from dredging activities or sediment from land runoff during heavy storms [70]. The Seychelles, along with Mauritius, now require adequate treatment of solid wastes and sewage. While Victoria, Mahé, has a sewage treatment plant, treatment was inadequate to significantly remove nutrients [70]. According to Ahamada, et al. [79], a new treatment plant became operational in 2001, though nothing was indicated as to the level of treatment or placement of the outfall. Nevertheless the above pre-ocean warming observations indicate how land-sourced pollution in highly developed areas can adversely impact coral reefs.

Prior to 1998, pollution seems to have controlled the abundance of algae and corals (Table 5); many sites, especially around the populated island of Mahé being overgrown with algae well before bleaching took place. Almost all the corals at Baie Ternay, Mahé, died in 1998 (from ocean warming event) [75], and the Marine Park Authority had to close the snorkel trail near Ile Moyenne and Ile Ronde because almost all the corals died (Figure 5) [75]. The 1998 ocean warming event resulted in live coral being reduced by $90 \%$ across the entire range of the inner islands of the Seychelles with no apparent depth refuge [76]. Because of their importance for biological diversity, island ecology, fishing and tourism (e.g., in 2003, an estimated $19 \%$ of visitors to the Seychelles participated in scuba 
diving and 65\% in snorkelling), the Seychelles has the unique opportunity to protect its reefs based on its philosophy of sustainable development, since between 2000 and 2004 mean live coral cover increased from $3.7 \%$ to $10.2 \%$ and is still gradually increasing [76].

Table 5. Underwater survey observations, Mahé and St Anne marine park, the Seychelles, 1990. Adapted from [70].

\begin{tabular}{|c|c|c|c|c|c|}
\hline $\begin{array}{c}\text { SITE \& SITE NUMBER } \\
\text { ON MAP } \\
\end{array}$ & $\begin{array}{l}\text { \% LIVE } \\
\text { CORAL }\end{array}$ & $\begin{array}{l}\text { \% DEAD } \\
\text { CORAL }\end{array}$ & $\%$ SILT & $\begin{array}{c}\% \text { Algal } \\
\text { Cover }\end{array}$ & $\begin{array}{c}\text { PREVALENT } \\
\text { ALGAL SPECIES }\end{array}$ \\
\hline \multicolumn{6}{|c|}{1990} \\
\hline $\begin{array}{l}\text { Baie Ternay National Park, } \\
\text { near lighthouse }\end{array}$ & 100 & 0 & 0 & 0 & - \\
\hline $\begin{array}{l}\text { Baie Ternay National Park, } \\
1 \mathrm{~km} \text { off of National Youth } \\
\text { Service camp, }\end{array}$ & $70-80$ & $20-30$ & 0 & 0 & - \\
\hline $\begin{array}{l}\text { Auberge Club De Seychelles } \\
100 \text { meters off shore }\end{array}$ & 95 & 5 & 0 & 0 & - \\
\hline $\begin{array}{l}\text { One kilometre offshore from } \\
\text { Victoria Sewage Treatment } \\
\text { Plant, in vicinity of outfall }\end{array}$ & 5 & 95 & $\begin{array}{c}\text { Minimal, } \\
\text { Colloids in } \\
\text { water column }\end{array}$ & 95 & Sargassum spp. \\
\hline $\begin{array}{l}\text { Brilliant Point, off lagoon } \\
\text { outlet, just off of and before } \\
\text { Runway Lights }\end{array}$ & $10-15$ & $85-90$ & 40 & 40 & Sargassum spp. \\
\hline $\begin{array}{l}\text { Ile Cachée, } \text { St. Anne } \\
\text { National Marine Park }\end{array}$ & 70 & 30 & 0 & $\leq 30$ & Turbinaria spp. \\
\hline $\begin{array}{l}\text { Ile Moyenne, St. Anne } \\
\text { Channel }\end{array}$ & $\geq 95$ & $\leq 5$ & 0 & $\leq 5$ & $\begin{array}{c}\text { Shallows ( } \leq 5 \text { feet }) \\
\text { dominated by } \\
\text { Turbinaria spp. }\end{array}$ \\
\hline \multicolumn{6}{|c|}{$\begin{array}{l}\text { Methodology: Line Transect Method. Principal author laid out five randomly placed } 25 \text { yard transects per site. } \\
\text { A } 2.25 \mathrm{ft}^{2}(1.5 \times 1.5 \mathrm{ft}) \text { quadrat was laid down at beginning, end and every five yards along marked chain, } \\
\text { and percent/live dead coral estimated and recorded at six points/transect on an underwater slate. The } \\
\text { percent live/dead coral averaged for each site. Underwater video also made and viewed to verify } \\
\text { underwater observations. }\end{array}$} \\
\hline
\end{tabular}


Figure 5. Underwater survey sites, Mahé Island, Seychelles. Source: Authors.

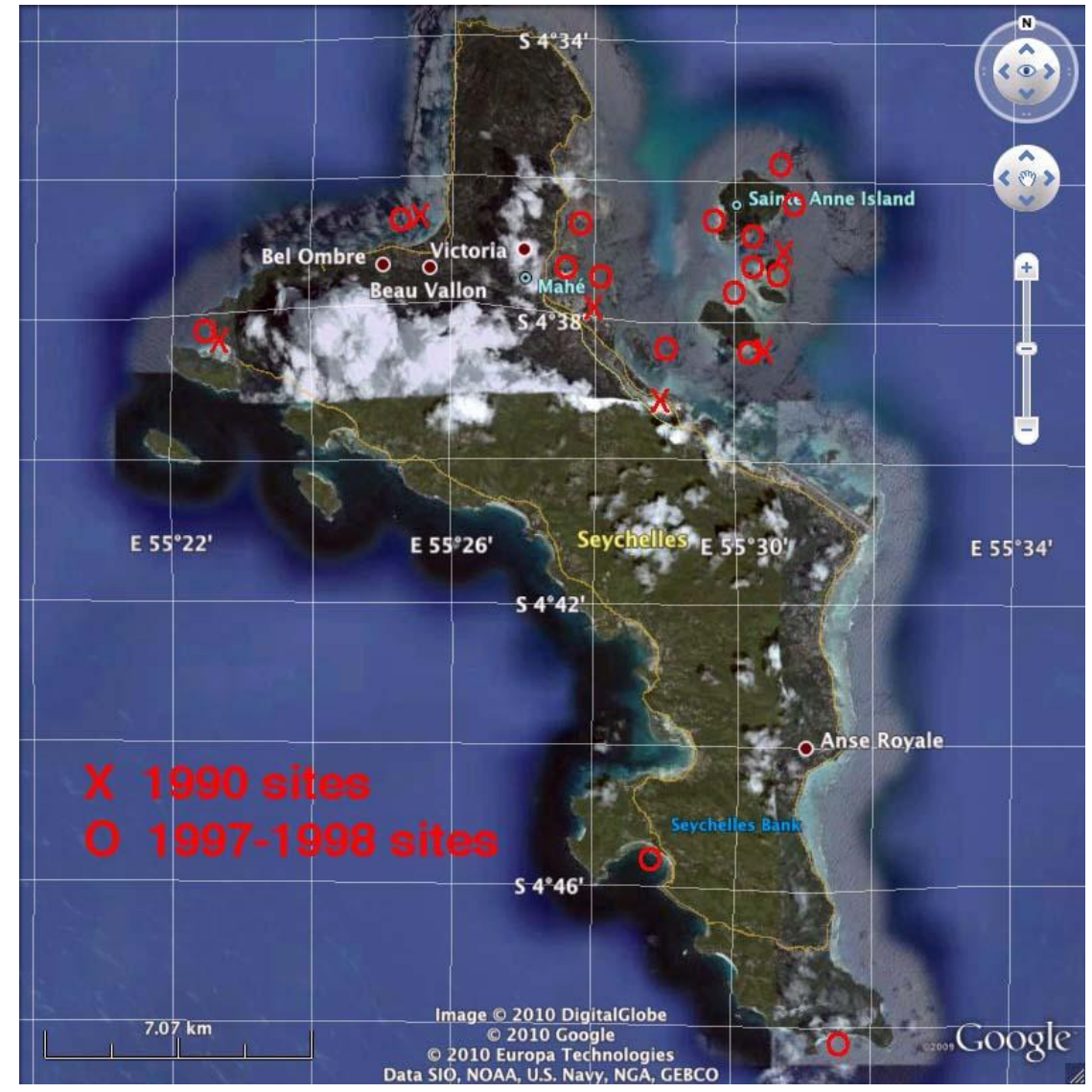

\section{Other Observations on Land-sourced Pollution in the Indian Ocean}

Underwater observations of coral health, macro-algae cover and pollution sources made by the principal author in the Western Indian Ocean are summarized in Table 6. Similar to observations by the authors in both the Caribbean and the East Coast of Africa/Western Indian Ocean, prior to the 1998 ocean warming event, coral reefs lying in watersheds with major agro-industrial activities and/or human populations that lacked adequate sewage treatment and disposal displayed coral reefs with high macro-algal cover.

Coral reefs in Mauritius in 2005 were found to mostly have a low abundance of live corals [73] even though Mauritius was only mildly affected by the 1998 ocean warming event [36]. Offshore uninhabited islands such as Ile au Aigrettes had very low algae cover, but reefs near populated areas, such as Flic en Flac, Grand Baie, and Bel Ombre were largely dead and had high levels of algae and cyanobacteria [73]. The major causes of degradation appear to be land-sourced sediments from erosion of agricultural land and deforested slopes, and nutrients from sewage and fertilizers [73].

Excessive growth of macro-algae, in response to nutrient fertilization from sewage, was noted around Male, Furana Fushi, Kura Bandos, Kurumathi, and Ihuru islands in the Maldives [17]. This was not observed on reefs remote from people. Many tourist islands also appear to be losing their reefs to algae. Unless steps are taken to deal with sewage on these islands, "all the inhabited and tourist islands will be sites of increased erosion due to reef deterioration". 
Table 6. Other observations in the Western Indian Ocean [80].

\begin{tabular}{|c|c|c|}
\hline$\underline{\text { SITE }}$ & CORAL REEF QUALITY & $\frac{\text { POSSIBLE CAUSES FOR CORAL }}{\text { DEGRADATION }}$ \\
\hline Stone Town, Zanzibar 1990 & 99\% Live Coral & $\begin{array}{l}1 \mathrm{~km} \text { offshore fringing island. } \\
\text { Reef near port \& new tourism hotels shows } \\
\text { signs of algal cover }\end{array}$ \\
\hline $\begin{array}{l}\text { Kilifi, Kenya, in front of sisal } \\
\text { plant, } 1991\end{array}$ & 99\% Dead Coral & $\begin{array}{l}\text { Coral reefs below sisal plant discharge dead \& } \\
\text { smothered in sediment from directly discharged } \\
\text { plant effluent, }\end{array}$ \\
\hline $\begin{array}{l}3 \mathrm{~km} \text { up coast from Kilifi sisal } \\
\text { plant }\end{array}$ & 99\% Live Coral & $\begin{array}{l}\text { Low density tourism homes-corals healthy, } \\
\text { though at low tide, local fishermen walk on } \\
\text { shallower coral reef to catch fish }\end{array}$ \\
\hline $\begin{array}{l}\text { Diego Suarez, Madagascar, } \\
\text { Off Military Base } 1991\end{array}$ & 99\% Live Coral & Very little development in the watershed \\
\hline $\begin{array}{l}\text { Ile De Maurice (Mauritius) } \\
\text { Grand Baie Aquarium } \\
\text { October 21, 1990, } \\
\text { NW/N Coast }\end{array}$ & $\begin{array}{l}\text { 95-98\% Dead Coral \& Covered } \\
\text { with Macro-Algae }\end{array}$ & $\begin{array}{l}\text { Coastal Watershed covered with tourist hotels, } \\
\text { and no or improper sewage treatment \& disposal } \\
\text { Inland watershed covered in sugar cane and } \\
\text { some tea with one of the highest rates of pesticide } \\
\text { application } / \mathrm{km}^{2} \text { anywhere in the world. }\end{array}$ \\
\hline $\begin{array}{l}\text { Big } T \text { and Fern Reefs, } \\
45 \text { minutes up coast from } \\
\text { Dar es Salaam, Tanzania, } \\
\text { off Sea Breeze Hotel, } \\
\text { December } 1997 . \\
5 \text { Dives }\end{array}$ & $99 \%$ Live Coral & $\begin{array}{l}\text { Low volume development in watershed with } \\
\text { a few hotels }\end{array}$ \\
\hline $\begin{array}{l}\text { Pemba, Mozambique, } \\
\text { March/April and December } \\
\text { 1998, four dives off } \\
\text { Nautilus Hotel }\end{array}$ & $\begin{array}{l}50-70 \% \text { macro-algae covered } \\
\text { coral reefs }\end{array}$ & $\begin{array}{l}\text { Pemba has human population of } 88,000 \& \text { no } \\
\text { sewage. People defecate on the beach; the case } \\
\text { all along the coast of Cabo Delgado Province. }\end{array}$ \\
\hline $\begin{array}{l}\text { Baixo Danae (Shallow Place) } \\
\text { 1990, } 50 \mathrm{~km}(31 \mathrm{mi}) \text { off of } \\
\text { Maputo and } 10 \mathrm{~km}(6.2 \mathrm{mi}) \\
\text { N/NW off Inhaca Island, } 1990\end{array}$ & $40 \%$ Live Coral & $\begin{array}{l}\text { Physically damaged, possibly from dynamite } \\
\text { fishing or trawlers dragging nets }\end{array}$ \\
\hline $\begin{array}{l}\text { Inhaca Island, off Maputo, } \\
\text { Mozambique, } 1990\end{array}$ & 60-80\% Dead Coral & $\begin{array}{l}\text { Visibility low, high algal cover on reefs — signs } \\
\text { of pollution from capital city \& refugee camps } \\
\text { on Inhaca }\end{array}$ \\
\hline \multicolumn{3}{|c|}{$\begin{array}{l}\text { Methodology: Principal author swims randomly over reef recording overall impressions. The uniqueness of this data is } \\
\text { that one person (important as a means of providing reasonable precision) had the opportunity to make observations of } \\
\text { coral reef quality over a large area of the Western Indian Ocean just before the } 1998 \text { ocean warming event. }\end{array}$} \\
\hline
\end{tabular}

In Malindi, Kenya, sediment and nutrient influx from the Sabaki River and coastal development along with over-fishing may have seriously impaired the reef's ability to recover from the 1998 ocean warming event. By 2004 coral cover had further declined by a mean of $5.1 \%$ at North Reef within the non-fished Malindi Marine National Park, and by 2.3\% on Leopard Reef within the fished Marine 
Reserve. Coral cover on North Reef is now twice that on Leopard Reef, while macroalgal cover on Leopard Reef is twice that on North Reef, possibly from decreased herbivores as a result of fishing [81]. No water quality data is provided, though this tends to support the "top down hypothesis".

\section{Sewage Pollution \& Treatment, Lessons from the Caribbean}

\subsection{Inadequacy of Secondary Sewage Treatment in Tropical Waters}

In watersheds with significant human populations, wherever quantitative nutrient data exists, coral reef degradation has been closely linked to inappropriate sewage treatment and disposal $[11,12,14,15,38,61,62,66,67,82]$. In the case of tourist resorts, most developers use prefabricated "package" plants, or septic tank systems, both designed to attain secondary levels of treatment. In many cases these systems malfunction, failing to attain the design-level of treatment. Regardless of operating performance, the effluent is discharged close to shore and/or enters into the nearshore waters indirectly through drainage ditches or through groundwater percolation [57,83]. Regardless, secondary treatment, without a long outfall, fails to meet both ecological (significant elimination of nutrients) and public health (significant elimination of viruses) objectives. Secondary treatment removes only a small portion of the nitrogen and phosphorus nutrients which over-fertilize coastal waters, causing harmful algae blooms that smother coral reefs and destroy fisheries habitat (Table 8) [11] and (Table 9) [62]. Septic tanks in coastal areas with high groundwater tables often malfunction during heavy rain events, flushing huge quantities of untreated effluent into coastal waters [11]. In addition, if chlorination to kill bacteria/viruses in secondary treatment is undertaken improperly, high residual chlorine levels in the effluent can be extremely toxic to aquatic life $[11,84]$.

\subsection{A Solution to Pollution Is Dilution for Sewage Disposal, Lessons from the Caribbean}

For decades the engineering adage "dilution is the solution to pollution" was applied worldwide: preliminary treatment with a long outfall. As land-sourced pollutants (e.g., organic matter/BOD, nutrients, pesticides, bacteria, viruses, heavy metals) move offshore they are naturally diluted and at some point in time are absorbed by the natural carrying capacity of the open-ocean waters, making them less of an ecological and public health risk.

The pollution problem, both in terms of public health and ecology, is a nearshore coastal phenomenon. The most fragile marine ecosystems, coral reefs and grassbeds are generally in shallow near shore waters, and it is between the coral reefs and the beaches where most bathing/swimming takes places. In both cases, land-sourced pollutants (e.g., from sewage, agricultural runoff) enter nearshore waters where they have an immediate impact on health of aquatic ecosystems and people.

Even if they functioned properly, secondary treatment plants do not adequately remove nutrients or viruses (Tables 7,8). While it takes ingestion of many bacteria to make a person ill, it takes the ingestion of only one viral unit to cause illness. In the U.S, outfalls are generally designed to assure a minimum of about two to three days before any of the discharge returns to coastal waters in order to maximize the likelihood of viral die-off from solar ultraviolet radiation [11,84]. 
Table 7. Comparison of pollution removal by wastewater treatment and disposal options.

\begin{tabular}{|c|c|c|c|c|}
\hline & \multicolumn{4}{|c|}{ Treatment Level-Effluent Concentrations } \\
\hline Parameter & Raw Sewage (a) & Primary (b) & Secondary (a) & Tertiary (a) \\
\hline $\begin{array}{l}\text { Total Suspended } \\
\text { Solids (TSS) }\end{array}$ & $100-350 \mathrm{mg} / \mathrm{L}$ & $35-123 \mathrm{mg} / \mathrm{L}$ & $25-40 \mathrm{mg} / \mathrm{L}$ & $5-16 \mathrm{mg} / \mathrm{L}$ \\
\hline $\begin{array}{l}\text { Biological Oxygen } \\
\text { Demand (BOD) }\end{array}$ & $100-300 \mathrm{mg} / \mathrm{L}$ & 65-195 mg/L & $25-35 \mathrm{mg} / \mathrm{L}$ & $5-15 \mathrm{mg} / \mathrm{L}$ \\
\hline Total Phosphorus as $\mathrm{P}$ & 6-20 mg/L & $\begin{array}{l}10 \% \text { Reduction }(\mathrm{c}) \\
\text { or less }\end{array}$ & $\begin{array}{c}8 \mathrm{mg} / \mathrm{L}(10 \% \text { Reduction }(\mathrm{b}) \\
\text { to } 30 \% \text { Reduction (c) }\end{array}$ & $\begin{array}{c}0.5-8 \mathrm{mg} / \mathrm{L} \\
99 \% \text { (b) Reduction }\end{array}$ \\
\hline Total Nitrogen as $\mathrm{N}$ & $20-85 \mathrm{mg} / \mathrm{L}$ & $\begin{array}{l}20 \% \text { Reduction }(\mathrm{c}) \\
\text { or less }\end{array}$ & $\begin{array}{c}30 \mathrm{mg} / \mathrm{L}(\mathrm{d}) \\
\text { (10\% Reduction (b) } \\
\text { to } 50 \% \text { Reduction(c) }\end{array}$ & $\begin{array}{c}\text { 3-30 mg/L (e) } \\
90 \% \text { (b) Reduction }\end{array}$ \\
\hline Viral Reduction & $\begin{array}{l}\text { 10,000 units/L } \\
\text { Max. Conc., } \\
1,000 \text { units/L } \\
\text { typical (f) }\end{array}$ & $0-3 \%$ (f) & $\begin{array}{l}90 \% \text { prior to Disinfection } \\
\qquad(\mathrm{g})\end{array}$ & $\begin{array}{c}\text { 90-99.99\% (h) Metallic } \\
\text { or Polyelectrolyte } \\
\text { Coagulation + PH } \\
\text { Adjustment }\end{array}$ \\
\hline $\begin{array}{l}\text { Total Coliforms } \\
\text { million organisms } \\
\text { per } 100 \mathrm{~mL}\end{array}$ & Average 30 (i) & Average 2 (i) & Average 0.001(i) & - \\
\hline $\begin{array}{l}\text { Fecal Coliforms } \\
\text { million organisms } \\
\text { per } 100 \mathrm{~mL}\end{array}$ & Average 4 (i) & - & - & - \\
\hline $\begin{array}{l}\text { (a) Source: [85] Note: L } \\
\text { (b) Source: [86] Note: I } \\
\text { Values shown computec } \\
\text { (c) Source: [87] (d) Lov } \\
\text { (e) Low value based on } \\
\text { nitrification-denitrificat } \\
\text { (f) Source: [88] (g) Sou } \\
\text { (h) Source: [90] (i) Sou }\end{array}$ & $\begin{array}{l}\text { W value weak sewa } \\
\text { licates that for prim } \\
\text { rom raw sewage di } \\
\text { value based on Twc } \\
\text { wo-stage lime coag } \\
\text { n. } \\
\text { e: [89] } \\
\text { : [91] All in Sourc }\end{array}$ & $\begin{array}{l}\text { e, high value strong } \\
\text { ry treatment there is } \\
\text { a shown in above ta } \\
\text { stage lime coagulati } \\
\text { lation, filtration and } \\
:[11,84]\end{array}$ & $\begin{array}{l}\text { a } 65 \% \text { reduction in TSS and } \\
\text { le. } \\
\text { ond filtration } \\
\text { selective ion exchange or bio }\end{array}$ & $\begin{array}{l}\% \text { reduction in BOD. } \\
\text { gical }\end{array}$ \\
\hline
\end{tabular}

Thus, to protect coral reefs, grassbeds and people, land-sourced pollutants should either not be discharged from land or should be discharged far enough offshore that they are not a threat to nearshore waters.

Modern secondary and tertiary treatment technologies require extreme expense and sophistication, neither of which is appropriate to the developing world. The cost of secondary treatment can be three to five times the cost of preliminary treatment with a long outfall, while solving neither ecological nor public health problems without an extended outfall that is an additional cost (Tables 7 and 8). Conventional tertiary treatment is even more expensive and sophisticated, but may also fail to reduce nutrient levels necessary for the protection of coral reefs without a long outfall [63]. However in the tropics, where plants grow year round, biological tertiary treatment using plants to absorb nutrients is 
highly effective [38]. However these more cost-effective options are usually ignored by sewage designers from temperate zones, where plants only grow part of the year.

Table 8. Comparison of sewage treatment levels proposed for Grand Anse Beach, Grenada. Adapted from [62].

\begin{tabular}{|c|c|c|c|c|}
\hline \multirow[t]{2}{*}{ Parameter } & \multicolumn{3}{|c|}{ Typical Secondary Treatment Effluent Characteristics } & \multirow{2}{*}{$\begin{array}{c}\text { Preliminary } \\
\text { Treatment } \\
\end{array}$} \\
\hline & Facultative & Aerated & Extended Aeration & \\
\hline TSS mg/L & 40 & $40-60$ & $20-30$ & 200 \\
\hline BOD mg/L & 30 & $30-45$ & $15-20$ & 190 \\
\hline Total Coliform (\#/100 mL) & $5,000-100,000$ & 10,000 & 10,000 & $40,000,000$ \\
\hline Nutrient Removal & Negligible & Negligible & Increase in Nitrates & None \\
\hline Detention Time (Days) & $?$ & $6-8$ & $18-24$ & None \\
\hline Construction Cost (US\$) & 1.5 million* & 1.5 million* & 1 million* & $300,000 *$ \\
\hline \multicolumn{5}{|l|}{ Annual Operation and } \\
\hline Maintenance Cost (US\$) & 35,000 & 150,000 & 150,000 & 35,000 \\
\hline Sludge & Medium & Low & High & $\begin{array}{l}\text { Minimal: still generates } \\
100 \mathrm{~kg} \text { dry weight of } \\
\text { solid waste/day }\end{array}$ \\
\hline Skill Required to Operate & Low & Medium & High & Low \\
\hline Land Area Required (Acres) & $8-10$ & 5 & 1 & 0.5 \\
\hline Hurricane Vulnerability & Low & High & High & Low \\
\hline Seismic Vulnerability & High & High & High & Low \\
\hline
\end{tabular}

*Note: Does not include cost of outfall.

For example, sewage treatment and disposal for up to 13,000 people off Grand Anse Beach, Grenada, using oceanographic surveys to locate predominant offshore currents, water quality monitoring and modelling, was preliminary treatment to remove grease, grit and large particulate matter (25-75 mm screens producing $100 \mathrm{~kg}$ dry weight of solids per day under maximum operation), followed by a 350-m (1,148 ft) outfall with a 100/1 diffuser. The net result was moving nutrient and viral contamination away from nearshore waters. Through dilution, nutrient and other water quality concentrations returned to background levels within $200 \mathrm{~m}$ of the discharge point [11,84]. Sealy [63] believes that more consideration should be given to the natural carrying capacity of the sea to treat domestic sewage in tropical coastal areas. This strategy has been pursued by Barbados, but potentially allows pollution to be carried to islands down-current.

Many tropical coasts have a narrow littoral zone (i.e., continental shelf), the depth dropping off very quickly, so preliminary treatment with a long outfall, the location based on proper oceanographic studies of prevailing offshore currents, may be a very cost-effective solution. This may be able to serve large tourism developments with many hotels and/or cities in places where there is persistent offshore flow from the disposal site.

Offshore disposal may not work off areas with shallow continental shelves or where many islands and associated reefs are contiguous, such as the Seychelles or Mauritius. Strong currents always directed away from coral reefs and the nearshore bathing zone do not exist in the Indian Ocean where 
there is strong reversal of most currents on a twice daily time scale by tides and on a twice annual time scale by monsoons. An example is Boracay in the Philippines, where local authorities ignored recommendations for treating sewage and recycling nutrients on land and chose simply to build a longer outfall. Since the winds reverse seasonally, this still carries inadequately treated sewage right back onto the beach half the year, causing algae proliferation and the cancellation of the World Windsurfing Championship because so many competitors got sick from severely polluted water [92,93].

Meanwhile, nutrients must be imported as fertilizers for agriculture, which could be provided by recycling instead of throwing them into the ocean and killing the reefs [38]. Once a secondary treatment plant is completed, St. Croix in the U.S. Virgin Islands has plans to shut down an offshore sewage pipe that was killing reefs, on grounds that local agriculture needs the recycled water and nutrients [94]. Florida has recently ordered all the offshore sewage outfalls closed, and mandated that the water be treated and recycled, but will take 15 years to fully implement these steps [95].

\subsection{Land Disposal of Sewage, Lessons from the Caribbean}

Although land disposal (e.g., spray irrigation and deep well injection-100s of feet into the ground below impervious layers or a high density aquifer which will trap wastewater) should be considered as options, these normally require at least secondary treatment $[11,86]$, and sophisticated technology and timing (e.g., effluent from spray irrigation usually sprayed at night in order to minimize the risk of viral aerosols contaminating humans). Operation and maintenance are a problem, although this could be minimized if hoteliers and/or a city were to pay the cost of a highly skilled technician to maintain the system. Often more effluent is produced than needed for irrigation [11]. In water-starved South Africa this may not be the case. Recycling of all effluents as irrigation is mandated in the dry Turks and Caicos Islands, and in many tourist areas golf courses beg for nutrient rich sewage effluent waters for irrigation, as costs of water (especially if produced by reverse osmosis) and fertilizers are so high.

The advantages of land disposal of secondarily treated sewage effluent are that advanced (tertiary) waste treatment is attained, and nutrients are recycled to land vegetation, which is usually nutrient-starved. This can vary from $82-99 \%$ removal of BOD, $92-98 \%$ removal of suspended solids, 0-90\% removal of nitrogen, 60-95\% removal of phosphorus, 50-95\% removal of metals and up to $98 \%$ of micro-organisms by the soil/plant system depending on the land application; sprinkler irrigation being most efficient, overland flow intermediate and infiltration-inflow being the least effective in removing pollutants [86]. Wastewater and nutrients should be used productively, and little or nothing should flow into nearshore waters [38]. There are also a number of potentially limiting factors with regard to irrigation and land treatment of effluent that must be addressed. These include:

- Storage Ponds. Even in the tropics, storage ponds may be necessary during the rainy season when land disposal may not be possible.

- Land Availability for Irrigation. A sizeable land area is required, which many small and densely populated tropical islands do not have but which should not be an issue in large islands and continental coastlines. 
- Heavy Metal Contamination of Crops from Effluent Irrigation. Certain crops concentrate heavy metals, which could cause plant toxicity problems (e.g., copper and zinc if municipal and industrial sewage are mixed, and boron from detergents in municipal sewage) [88].

- Viral, Bacterial and Parasitic Contamination of Crops and People from Effluent Irrigation. Primary (preliminary) treated sewage should not be used to irrigate crops for human consumption. The USEPA advises that only crops that are to be used for canning or similar processes be irrigated with secondarily treated effluent—which implies no irrigation with secondary effluent of fresh produce [88]. Helminth (e.g., ascariasis, fascioliasis, cysticercosis and tapeworm) ova and parasitic worms as well as Schistosomiasis have been known to survive sewage treatment processes and chlorination. Viruses and many pathogenic bacteria can survive chlorinated secondarily treated effluent. If sprinkler irrigation is used, this could contaminate crops and workers. Likewise, it would not be wise to use such effluent on golf courses where clients could be contaminated [88]; though spraying at night might work.

- Nutrient Removal from Irrigation and Other Land Disposal Methods. The amount of wastewater that can be applied is determined by balancing the nutrient load of wastewater against the nutrient removal capacity of the soil [88] and crops/vegetation. Soils tend to have a high ability to remove phosphorus so that this should not limit irrigation with effluent. Nitrogen loads need to be balanced against crop removal [88]. If vegetation is grown for livestock feed, care must be taken that nitrate does not accumulate in the stems and leaves to toxic levels [88]. In porous limestone areas, surrounding groundwater and nearshore waters need careful monitoring to make sure that nutrient contamination does not occur-though monitoring should be a part of any system to assure effectiveness.

Land discharge of sewage can be a problem on small densely populated islands, but not on large islands or continental coasts, such as Eastern Africa's mainland, where it can be pumped well inland from the coast possibly for agricultural irrigation, and operated by a highly skilled technician to assure proper secondary treatment. The coastal zone is being planned for tourism development south of Maputo between Mozambique and South Africa in the vicinity of the Maputo Elephant Reserve. As an alternative to coastal discharges, this area has extensive wetlands that could possibly be part of a secondary treatment/overland flow system, with the already nutrient rich wetlands polishing the final effluent. This would require modelling and monitoring to insure the integrity of the wetlands. Estuarine systems, such as the Greater St. Lucia wetlands in South Africa, act as nutrient purifying systems as nutrients from catchments are absorbed by vegetation, resulting in cleaner water entering the sea [46].

\section{High Paying Low Volume Tourism Option, Lessons from the Caribbean}

A low-cost option that should be strongly considered is to remain on septic tanks, but restrict tourism to low-volume, exclusive, high-paying, and within the assimilative capacity of the environment to absorb the pollution. A careful study would need to be undertaken of soils, percolation rates, height of the groundwater table after rains (a high groundwater table after rains could cause septic tank malfunctioning and direct discharge of sewage into coastal waters) and the dilutional capacity of the surrounding coastal zone. This may require the use of a sanitary engineer, soil scientist, 
groundwater specialist and ecologist (e.g., engineering consulting firm), with installation of appropriately mounded septic systems developed for coastal areas with high water tables, situated well inland.

Ultimately, developers should be required to pay for an environmental assessment that looks at a number of alternative treatment options, permitting a cost-benefit analysis that allows stakeholders to determine short- and long-term environmental and economic tradeoffs. A long-term water quality and reef-monitoring program would be required - all a part of the cost of doing business if long-term sustainability is desired. Tourist developments should bear the costs for such environmentally conserving programs through higher user fees.

\section{Why Addressing Sewage Linked to Tourism is Important Economically}

In addition to the protection of biodiversity that has already been discussed, addressing the issue of sewage and land-sourced pollution in general is important economically. Economics plays a central role in political decision making. Travel and tourism in the Caribbean contributes to about $25 \%$ of the GDP (Gross Domestic Product) of these island states and is expected to grow to $35 \%$ over the next decade [96]. In contrast, tourism accounts for about 1.2\% of Mozambique's GDP [97], 9.7\% of Tanzania's GDP [98], 12\% of Kenya's GDP [99], 15.4\% of Egypt's GDP [98], 31.6\% of Mauritius's GDP [98] and $60.2 \%$ of the Seychelles GDP [98]. With the exception of Tanzania and Kenya that are renowned for their "Big 5" game parks, but have exceptional potential for coastal tourism linked to their coral reef ecosystem, tourism in the other countries is almost exclusively dependent upon healthy coral reefs, related seafood and white sandy beaches. In addition, artisanal fishing is an important component economically and nutritionally to coastal communities in this region of the world. For instance, in Tanzania, it is estimated that coral reefs are critical for $70 \%$ of the coastal fisheries [48]. Decision makers from Africa, Asia, and Pacific nations must make protection and conservation of coral reef ecosystems from pollution and over-fishing every bit as important as the conservation of terrestrial mega-fauna and its habitat.

\section{Conclusions}

Coral reefs are threatened globally, primarily from land-sourced pollution and more recently from global warming. Most of the Indian Ocean and Pacific, where the majority of the world's coral reefs are found, are fortunate that most of their coastline, other than a few large cities, is relatively undeveloped, as the Caribbean and Florida Keys were back in the 1960s and early 1970s.

Improperly treated sewage, as a key component of land-sourced pollution, is one of the prime causes of nutrient pollution, since sewage and grey water is often literally dumped on top of coral reefs. Thus tourism, among other land-sourced activities, is destroying the very attractions that bring tourists to the world's coastal zones. Other causes of reef degradation include sedimentation due to poor land use (e.g., cultivation without appropriate soil conservation or improperly located agricultural activities, misuse of agro-chemicals, over-grazing), and industrial pollution.

Ultimately, coral reefs are not only important for marine biodiversity, fisheries, tourism, and shore protection, but contribute and/or have the potential to significantly contribute to the economies of most Indian Ocean and Pacific nations. Developers, governments and residents living in key watersheds critical to the survival of coral reefs need to be sensitized that sustainable development costs 
(e.g., proper location of lodges behind primary dunes, appropriate sewage technology, etc.), while securing investment in the long-term are similar to unsustainable development costs. However, once lost, even if the sources of pollution are eliminated, it can take generations or more for the coral reefs to regenerate. Global and ocean warming, while issues, must be dealt with on an international scale, such as through the United Nations Framework Convention on Climate Change. But if we wait for the larger issues to be dealt with first, land-sourced pollution may have already wiped out the coral reefs. Ultimately, one must ask if humankind wishes to see healthy colourful coral reef or dead and dying reef that is becoming so common across the globe. Africa, Asia, and the Pacific have a chance to learn from the hard lessons provided by the near destruction of the Caribbean's coral reefs by over-development. The choice is ours!

\section{References}

1. Goreau. T.J. Global Change, Coral Reef Restoration, Sustainable Fisheries, and Renewable Ocean Energy Development; World Summit on Sustainable Development, Civil Society Global Forum on the Oceans, NASREC: Johannesburg, South Africa, 29 August 2002.

2. Spalding, M.D.; Ravilious, C.; Green, E.P. World Atlas of Coral Reefs; UNEP World Conservation Monitoring Centre, University of California: Berkeley, CA, USA, 2001.

3. Laborel, J. West African reef corals: A hypothesis on their origin. In Proceedings of the Second International Coral Reef Symposium; The Great Barrier Reef Committee: Brisbane, Australia, 1974; Volume 1, pp. 425-443; Available online: http://www.reefbase.org/resource_ center/publication/icrs.aspx?icrs=ICRS2 (accessed on 9 September 2010).

4. Freiwald, A.; Roberts, J.M. Cold-water Corals and Ecosystems; Erlangen Earth Conference Series Xxxii; Springer-Verlag: New York, NY, USA, 2005.

5. University of Massachusetts. Corals of the Cape Verde Islands; Available online: http://www.umassd.edu/specialprograms/caboverde/corals.html (accessed on 10 June 2010).

6. Floeter, S.R. The Evolution and Ecology of a Poorly Known Atlantic Biodiversity Hotspot; National Geographic Committee for Research \& Exploration: Washington, DC, USA, 2006; Available online: http://www.lbmm.ufsc.br/projetos/stome/NGS_STome_Report.pdf (accessed on 10 June 2010).

7. Nelson, F. East Africa: Trends in Coastal Tourism \& Strategies for Promoting Sustainable Development; Marine Program, World Wildlife Fund: Washington, DC, USA, 2007; Available online: http://www.responsibletravel.org/resources/documents/reports/FINAL_REPORT_Fred_ Nelson_Jan_08.pdf (accessed on 10 June 2010).

8. Goreau, T.F.; Goreau, N.I.; Goreau, T.J. Corals and coral reefs. Sci. Am. 1979, 241, 14-136.

9. Sea Slug Forum. What Are Zooxanthellae? Available online: http://www.seaslugforum.net/ zoox1.htm (accessed on 10 June 2010).

10. Shinn, E.A. What is really killing the corals? Sea Frontiers 1989, 35, 72-81.

11. DeGeorges, A. Land-Based Pollution and Its Impact on Coral Reefs and Related Ecosystems, the Caribbean Experience Implications for East African Coastal Tourism; Regional Environmental Advisor, U.S. Agency for International Development: Washington, DC, USA, 1990. 
12. Hunte, W. A Survey of Corals near Grand Anse Beach, Grenada; OAS: Washington, DC, USA, 1987.

13. Hunte, W. Short-term perspectives and marine resources in the Caribbean. In The Twenty-Fifth Anniversary Lecture Series of the University of the West Indies; Bellairs Research Institute: St. James, Barbados, 1989.

14. Tomascik, T.; Sander, F. Effects of eutrophication on reef-building corals. II-Structure of scleractinian coral communities on fringing reefs, Barbados, West Indies. Mar. Biol. 1987, 94, 53-75.

15. Tomascik, T.; Sander, F. Effects of eutrophication on reef-building corals. III-Reproduction of the reef-building coral Porites porites. Mar. Biol. 1987, 94, 77-94.

16. Regional Overview of Environmental Problems and Priorities Affecting the Coastal and Marine Resources of the Wider Caribbean Region; CEP Technical Report 2; United Nations Environment Programme, Caribbean Environment Programme: Kingston, Jamaica, 1989; Available online: http://www.cep.unep.org/publications-and-resources/technical-reports/tr02en.pdf (accessed on 9 September 2010).

17. Goreau, T.J. Damage to Maldivian Reefs from Mining, sea Level Rise, Sewage and Global Warming: Recommendations for Coral and Shore Protection; Report to Maldives Department of Fisheries; Global Coral Reef Alliance: Chappaqua, NY, USA, 1998.

18. GESAMP. A Sea of Troubles. Joint Group of Experts on the Scientific Aspects of Marine Environmental Protection. (IMO/FAO/UNESCO-IOC/WMO/WHO/IAEA/UN/UNEP) and Advisory Committee on Protection of the Sea; UNEP: Nairobi, Kenya, 2001; Available online: http://unesdoc.unesco.org/images/0012/001229/122986e.pdf (accessed on 9 September 2010).

19. Littler, M.L.; Littler, D.S.; Brooks, B.L. Harmful algae on tropical coral reefs: Bottom-up eutrophication and top-down herbivory. Harmful Algae 2006, 5, 565-585; Available online: http://www.littlersworks.net/reprints/Littler2006a.pdf (accessed on 23 July 2010).

20. Protecting the Oceans from Land-Based Activities-Land-Based Sources and Activities Affecting the Quality and Uses of the Marine, Coastal and Associated Freshwater Environment; Joint Group of Experts on the Scientific Aspects of Marine Environmental Protection, UNEP: Washington, DC, USA, 2001; Volume 71.

21. Goreau, T.J.; Hayes, R.L. A Survey of Coral Reef Bleaching in the South Central Pacific during 1994; Report to the International Coral Reef Initiative; U.S. Department of State, Global Coral Reef Alliance: Chappaqua, NY, USA, 1995; Available online: http://globalcoral.org/coral_reef_ bleaching_in_the_sout.htm (accessed on 9 September 2010).

22. Nixon, S.W. Coastal marine eutrophication: A definition, social causes, and future concerns. Ophelia 1995, 41, 199-219.

23. Anderson, D.M.; Gilbert, P.M.; Burkholder, J.M. Harmful algal blooms and eutrophication nutrient sources, composition, and consequences. Estuaries 2002, 25, 704-726.

24. Hallegraeff, G.M. Harmful algal blooms: A global overview. Monogr. Oceanog. Methodol. 2003, $11,25-49$.

25. Littler, M.L.; Littler, D.S. Top-down vs. bottom-up controls of coral reef community structure. Present at Ninth International Coral Reefs Symposium Abstracts, Bali, Indonesia, 23-27 October 2000. 
26. Bell, P. Eutrophication and coral reefs: Some examples in the Great Barrier Reef lagoon. Water Res. 1992, 26, 553-568.

27. Lapointe, B.E.; Littler, M.; Littler, D. Modification of benthic community structure by natural eutrophication: The Belize Barrier Reef. In Proceedings of 7th International Symposium on Coral Reefs; Committee on Coral Reefs of the International Association of Biological Oceanographers and the International Society for Reef Studies: Guam, Micronesia, 1992; Volume 1, pp. 323-334; Available online: http://www.reefbase.org/download/download.aspx?type=1\&docid=10322 (accessed 9 September 2010).

28. Lapointe, B.E.; Tomasko, D.A.; Matzie, W.R. Eutrophication and tropic state classification of seagrass communities in the Florida Keys. Bull. Mar. Sci. 1994, 54, 696-717.

29. McClanahan, T.R.; Muthiga, N.A. Changes in Kenyan coral reef community structure and function due to exploitation. Hydrobiologia 1988, 166, 269-276.

30. Hughes, T.P. Catastrophes, phase shifts, and large-scale degradation of a Caribbean coral reef. Science 1994, 265, 1547-1551.

31. McClanahan, T.R. Primary succession of coral-reef algae: Differing patterns on fished versus unfished reefs. J. Exp. Mar. Biol. Ecol. 1997, 218, 77-102.

32. Hawkins, J.P.; Roberts, C.M. Effects of artisanal fishing on Caribbean coral reefs. Conserv. Biol. 2004, 18, 215-226.

33. Goreau, T.J. Bleaching and reef community change in Jamaica: 1951-1991. Symposium on long term dynamics of coral reefs. Am. Zool. 1992, 32, 683-695.

34. McClanahan, T.R.; Muthiga, N.A.; Maina, J.; Kamukuru, A.T.; Saleh A.S.; Yahya, S.A.S. Changes in northern Tanzania coral reefs during a period of increased fisheries management and climatic disturbance. Aquat. Conserv. Mar. Freshwat. Ecosyst. 2009, 19, 758-771.

35. Super Reefs Fend Off Climate Change, Study Says. Science Daily, 27 April 2009; Available online: http://www.sciencedaily.com/releases/2009/04/090423132612.htm (accessed on 10 June 2010).

36. Goreau, T.J.; McClanahan, T.; Hayes, R.; Strong, A. Conservation of coral reefs after the 1998 global bleaching event. Conserv. Biol. 2000, 14, 5-15.

37. Anderson, D.M.; Gilbert, P.M.; Burkholder, J.M. Harmful algal blooms and eutrophication nutrient sources, composition, and consequences. Estuaries 2002, 25, 704-726.

38. Goreau, T.J. Case study: Waste nutrients: Impacts on coastal coral reefs and fisheries, and abatement via land recycling. In Proceeding of United Nations Expert Meeting on Waste Management in Small Island Developing States, Havana, Cuba, 27 October-1 November 2003; Small Island Developing States Network of the United Nations Department of Economic and Social Affairs (UN-DESA): New York, NY, USA, 2003; Available online: http://www.sidsnet.org/docshare/other/20040310124457_case_study_by_Thomas_J_Goreau_on_ waste_mgmt_2003.pdf (accessed on 9 September 2010).

39. Bell, P.R.F.; Lapointe, B.E.; Elmetri, I. Re-evaluation of ENCORE: Support for the Eutrophication Threshold Model for Coral Reefs. Ambio 2007, 36, 416-424.

40. McClanahan, T.R. Coral reef use and conservation. In Coral Reefs of the Indian Ocean-Their Ecology and Conservation; McClanahan, T.R., Sheppard, C.R.C., Obura, D.O., Eds.; Oxford University: Oxford, UK, 2000; pp. 39-76. 
41. McManus, J.W.; Menez, L.A.B.; Kesner-Reyes, K.N.; Vergara, S.G.; Ablan, M.C. Coral reef fishing and coral-algal phase shifts: Implications for global reef status. ICES J. Mar. Sci. 2000, 57, 572-578.

42. Barrow, E.; Gichohi, H.; Infield, M. Rhetoric or Reality? A Review of Community Conservation and Practice in East Africa; Evaluating Eden Series No 5; International Institute for Environment and Development (IIED): London, UK, 2000; Available online: http://www.iied.org/pubs/ pdfs/7807IIED.pdf (accessed on 10 June 2010).

43. DeGeorges, A. Field Notes and Underwater Photography, Grand Anse Beach Sewage Treatment Project; Regional Environmental Management Specialist (REMS)/Caribbean, U.S. Agency for International Development (USAID), Regional Development Office for the Caribbean (RDO/C): Bridgetown, Barbados, 1988.

44. Paddack, M.J.; Cowen, R.K.; Sponaugle, S. Grazing pressure of herbivorous coral reef fishes on low coral-cover reefs. Coral Reef 2006, 25, 461-472.

45. Sandin, S.A.; Sampayo, E.M.; Vermeij, M.J.A. Coral reef fish and benthic community structure of Bonaire and Curaçao, Netherlands Antilles. Caribb. J. Sci. 2008 44, 137-144.

46. Assessment of major transboundary problems and issues. In Transboundary Diagnostic Analysis of Land-Based Sources and Activities in the Western Indian Ocean Region; United Nations Environment Programme and Environment: Washington, DC, USA, 2008; Available online: http://www.iwlearn.net/iw-projects/Fsp_11279946939/reports/wiolab-tda (accessed on 26 July 2010).

47. Goreau, T.J.; Fisher, T.; Perez, F.; Lockhart, K.; Hibbert, M.; Lewin, A. Turks and Caicos Islands 2006 coral reef assessment: Large-scale environmental and ecological interactions and their management implications. Rev. Biol. Trop. 2008, 56, 25-49.

48. Twong'o, T.K.; Sikoyo, G.M. Status of the resources of coastal aquatic ecosystems of Kenya and Tanzania. In Shared Ecosystems of East Africa: Institutional Analysis; Wakhungu, J.W., Sikoyo, G.M., Eds.; African Centre for Technology Studies (ACT): Nairobi, Kenya, 2003.

49. Ten Years after Bleaching-Facing The Consequences of Climate Change in the Indian Ocean; CORDIO Status Report 2008; Obura, D.O., Tamelander, J., Linden, O., Eds.; Coastal Oceans Research and Development in the Indian Ocean: Mombasa, Kenya, 2008; Available online: http://www.cordioea.org/storage/status-reports-full/CORDIO\%202008-Summaries.pdf (accessed on 10 June 2010).

50. Smith, S.V.; Kimmerer, W.J.; Laws, E.A.; Brock, R.E.; Walsh, T.W. Kaneohe Bay sewage diversion experiment: Perspectives on ecosystem responses to nutritional perturbation. Pac. Sci. 1981, 35, 279-385; Available online: http://scholarspace.manoa.hawaii.edu/handle/10125/616 (accessed on 22 July 2010).

51. DeGeorges, A. An Integrated Approach to Development of Commercial Fishing and Mariculture in Belize. Fisheries Annex. Commercialization of Alternative Crops Amendment (505-008); USAID: Washington, DC, USA, 1989.

52. DeGeorges, A. Contribution to the Project Paper on Protected Areas Resource Conservation (PARC), Montego Bay Marine Park Component; U.S. Agency for International Development (USAID): Kingston, Jamaica, 1988. 
53. DeGeorges, A. Biodiversity and Natural Resources Management; Draft field notes; Regional Environmental Management Specialist (REMS)/Caribbean, U.S. Agency for International Development (USAID), Regional Development Office for the Caribbean (RDO/C): Bridgetown, Barbados, 1988.

54. DeGeorges, A; Ford, L.B. Analysis of Needs for Conservation of Tropical Forests and Biological Diversity in Haiti; U.S. Agency for International Development (USAID): Port-au-Prince, Haiti, 1988.

55. Johnson, N.; DeGeorges, A.; Jackson, I.; Talbot, K.; Teytaud, R. Biological Diversity and Tropical Forest Assessment for the Eastern Caribbean; Prepared for the U.S. Agency for International Development (USAID); Regional Development Office for the Caribbean (RDO/C) by the Centre for International Development and the Environment, USAID/RDO/C: Bridgetown, Barbados, 1988.

56. Puerto Rico Workshop on Land-based Sources of Marine Pollution in the Wider Caribbean Region, San Juan, Puerto Rico, 7-9 August 1989; Caribbean Islands Directorate, U.S. Man and the Biosphere Program, OES/ENR/MAB, Department of State: Washington, DC, USA, 1989.

57. Ward, F. Florida's coral reefs are imperilled. Nat. Geogr. 1990, 178, 115-132.

58. WWF. Proposal to Establish a National Marine Park at les Arcadins, Haiti; Submitted to USAID Port-au-Prince, Haiti by World Wildlife Fund (WWF)-US in association with Wilcox Associates: Washington, DC, USA, 1986.

59. Maragos, J.E. Restoring coral reefs with emphasis on Pacific reefs. In Restoring the Nation's Marine Environment; Thayer, G.W., Ed.; A Maryland Sea Grant Program: College Park, MD, USA, 1992.

60. Restoring the Nation's Marine Environment; Thayer, G.W., Ed.; Maryland Sea Grant Book, Maryland Sea Grant College, University of Maryland: College Park, MD, USA, 1992.

61. Lapointe, B.E.; Barile, P.J.; Yentsch, C.S.; Littler, M.M.; Littler, D.S.; Kakuk, B. The relative importance of nutrient enrichment and herbivory on macro-algal communities near Norman's Pond Cay, Exumas Cays, Bahamas: A 'natural' enrichment experiment. J. Exp. Mar. Biol. Ecol. 2004, 298, 275-301.

62. Bellairs Research Institute. Sewage Treatment and Disposal for the Grand Anse Area of Grenada; Prepared for the U.S. Agency for International Development (USAID); Regional Development Office for the Caribbean (RDO/C) and The Organization of American States, USAID/RDO/C: Bridgetown, Barbados, 1989.

63. Sealy, H. The LBSMP-Implementation Challenges. In Proceedings of the UNEP Workshop on Nutrient Removal Technology, Caribbean Water and Wastewater Association (CWWA), Trinidad, WI, USA, 9-13 December 2002.

64. APHA Standard Methods for the Examination of Water and Wastewater, 14th ed.; American Public Health Association, American Water Workers Association, Water Pollution Control Federation, APHA Offices: Washington, DC, USA, 1975.

65. Lapointe, B.E. Nutrient Water Quality Standards for Coral Reefs. Division of Marine Science, Harbor Branch Oceanographic Institution, Ft. Pierce, FL, USA. Personal communication, 29 April 2004. 
66. Goreau, T.J.; Thacker, K. Coral reefs, sewage, and water quality standards. In Proceedings of the $3 r d$ Caribbean Water and Wastewater Association (CWWA) Conference, Water and Wastewater Needs for the Caribbean: 21st Century, Kingston, Jamaica, 3-7 October 1994; Volumn 3; pp. 98-116.

67. Lapointe, B.E. Phosphorus-rich waters at Glovers reef, Belize. Mar. Pollut. Bull. 2004, 48, 193-195.

68. Lapointe, B.E. Summary of Literature Coral Reef Water Quality Standards. Division of Marine Science, Harbor Branch Oceanographic Institution, Ft. Pierce, FL, USA. Personal communication, 27 April 2004.

69. Goreau, T.J. Macro/Epiphytic Algae Species, APA and Sewage/Nutrient Pollution. Global Coral Reef Alliance, Cambridge, MA, USA. Personal communication, 30 April 2004.

70. DeGeorges, A. Coral Reef Survey of Mahé and the St. Anne Marine Park with Regard to Land Reclamation Around Victoria, Mahé, Seychelles, 19 October 1990; Prepared for USAID and Departments of Planning and the Environment; Government of the Seychelles: Mahé, the Seychelles, 1990.

71. Goreau, T.J. Coral Bleaching in the Seychelles. Impacts and Recommendations; Report to Seychelles Marine Park Authority; Global Coral Reef Alliance: Chappaqua, NY, USA, 1998.

72. Rajasuryia, A. Status Report on the Condition of Reef Habitats in Sri Lanka. In Coral Reef Degradation in the Indian Ocean (CORDIO); Status Report 2002; Linden, O., Souter, D., Wilhelmsson, D., Obura, D., Eds.; CORDIO Department of Biology and Environmental Science, University of Kalmar: Kalmar, Sweden, 2002; pp. 139-148.

73. Goreau, T.J. Mauritius Marine Management Notes; Global Coral Reef Alliance: Cambridge, MA, USA, 2005.

74. Goreau, T.J. Coral Recovery from Bleaching in Alphonse and Bijoutier, Seychelles; Global Coral Reef Alliance: Chappaqua, NY, USA, 1998.

75. Goreau, T.J. Coral Recovery from Bleaching in Seychelles; Report to Seychelles Marine Park Authority; Global Coral Reef Alliance: Chappaqua, NY, USA, 1998.

76. Graham, N.A.J.; Wilson, S.K.; Jennings, S.; Polunin, N.V.C.; Bijoux, J.P.; Robinson, J. Dynamic fragility of oceanic coral reef ecosystems. National Academy of Sciences, PNAS 2006, 103, 425-428.

77. Regional Seas Reports and Studies; Marine Pollution in the East African Region, United Nations Environmental Programme, UNEP: Washington, DC, USA, 1982; Volume 8; Available online: http://www.unep.org/regionalseas/publications/reports/RSRS/pdfs/rsrs008.pdf (accessed on 9 September 2010).

78. Ahamada, S.; Bijoux, J.; Bigot, L.; Cauvin, B.; Kooonjul, M.; Maharavo, J.; Meunier, S.; Moine-Picard, M.; Quod, J.P.; Pierre-Louis, R. Status of the coral reefs of the South West Indian Ocean island states. In Status of Coral Reefs of the World: 2004; Wilkinson, C., Ed.; Global Coral Reef Monitoring Network and Australian Institute of Marine Science: Townsville, QLD, Australia, 2004; pp. 189-211; Available online: http://www.reefbase.org/main.aspx (accessed on 9 September 2010). 
79. Ahamada, S.; Bigot, L.; Bijoux, J.; Jean, J.M.; Meunier, S.; Moine-Picard, M.; Paupiah, N. Status of Coral reefs in the South West Indian Ocean Island node: Comoros, Madagascar, Mauritius, Reunion and Seychelles. In Status of Coral Reefs of the World: 2002; Wilkinson, C., Ed.; Global Coral Reef Monitoring Network and Australian Institute of Marine Science: Townsville, QLD, Australia, 2002; pp. 79-100; Available online: http://www.reefbase.org/main.aspx (accessed on 9 September 2010).

80. DeGeorges, A. Field notes/dive log of underwater observations off the East Coast of Africa, 1990-1998. Unpublished.

81. Lambo, A.L.; Ormand, R.F.G. Continued post-bleaching decline and changed benthic community of a Kenyan coral reef. Mar. Pollut. Bull. 2006, 52, 1617-1624.

82. Tomascik, T.; Sander, F. Effects of eutrophication on reef-building corals. I-Growth rate of the reef building coral Montastraea annularis. Mar. Biol. 1985, 87, 143-155.

83. Archer, A. Regional Survey of Sewage Disposal in the Caribbean Islands; U.N. Economic Commission for Latin America and the Caribbean: New York, NY, USA, 1988.

84. DeGeorges, P.A.; Reilly, B.K. A Critical Evaluation of Conservation and Development in Sub-Saharan Africa; Edwin Mellen: Lewiston, ID, USA, 2008.

85. Process Design Manual for Land Treatment of Municipal Wastes; USEPA: Cincinnati, OH, USA, 1977.

86. Environmental Pollution Control Alternatives; USEPA: Cincinnati, OH, USA, 1976.

87. Clark, J. Coastal Ecosystem Management. A Technical Manual for the Conservation of Coastal Resources; John Wiley \& Sons: Hoboken, NJ, USA, 1977.

88. Water Quality Criteria 1972. "Blue Book". A Report of the Committee on Water Quality Criteria; U.S. Government Printing Office: Washington, DC, USA, 1972.

89. Human Viruses in the Aquatic Environment: A Status Report with Emphasis on the EPA Research Program; Report to Congress; Environmental Research Center (ORD): Cincinnati, OH, USA, 1978.

90. Critical Review of Virus Removal by Coagulation Processes and pH Modifications; Municipal Environmental Research Laboratory, Office of Research and Development, U.S. Environmental Protection Agency: Cincinnati, OH, USA, 1980.

91. Zison, S.W.; Haven, K.F.; Mills, W.B. Water Quality Assessment. A Screening Method for Non-Designated 208 Areas; USEPA: Cincinnati, OH, USA, 1977.

92. Goreau, T.; Goreau, M.; Cervino, J. Water Quality and Coral Reef Health in Boracay, El Nido, Isla Verde, and Balicasag, Philippines; Report to the Ministry of Tourism, Philippines; Global Coral Reef Alliance: Cambridge, MA, USA, 1997; Available online: http://globalcoral.org/Water Quality and Coral Reef Health In Boracay,.htm (accessed on 9 September 2010).

93. Goreau, T.J. Boracay Environmental Restoration, Water Quality, and Sustainable Energy: Current Situation and Future Prospects; Global Coral Reef Alliance: Cambridge, MA, USA, 2007; Available online: http://globalcoral.org/boracay_environmental_restoratio.htm (accessed on 9 September 2010).

94. Wastewater-VI Senate Environmental Briefing Book; Virgin Islands Waster Management Authority: Christiansted, VI, USA, 2010; Available online: http://www.viwma.org/wastewater BBook.aspx (accessed on 10 June 2010). 
95. Brown, T. Florida Moves to Curb Ocean Sewage Dumping. Reuters, 23 April 2008; Available online: http://www.reuters.com/article/domesticNews/idUSN2230092520080423 (accessed on 10 June 2010).

96. Burke, L.; Kura, Y; Kassem, K.; Revenga, C.; Spalding, M.; McAllister, D. Pilot Analysis of Global Ecosystems: Coastal Ecosystems; World Resources Institute: Washington, DC, USA, 2001; Available online: http://pdf.wri.org/page_coastal.pdf (accessed on 22 July 2010).

97. MOT. Strategic Plan for the Development of Tourism in Mozambique (2004-2013); Ministry of Tourism, Republic of Mozambique: Maputo, Mozambique, 2004; Available online: http://tourism invest.org/Mozambique/downloads/tourism\%20sector\%20background/Strategies, \%20plans/Plano _Estrategico_en_MITUR.pdf (accessed on 22 July 2010).

98. Africa Environment Outlook 2-Our Environment, Our Wealth; United Nations Environment Programme: Nairobi, Kenya, 2006; Available online: http://www.unep.org/DEWA/Africa/docs/ en/AEO2_Our_Environ_Our_Wealth.pdf (accessed on 22 July 2010).

99. About Kenya \& the Coast; Mombasa \& Coastal Tourism Association: Mombasa, Kenya, 2010; Available online: http://kenyacoast.net/mombasa.htm (accessed on 22 July 2010).

(C) 2010 by the authors; licensee MDPI, Basel, Switzerland. This article is an open access article distributed under the terms and conditions of the Creative Commons Attribution license (http://creativecommons.org/licenses/by/3.0/). 